\title{
RAMSES II HELPS THE DEAD: AN INTERPRETATION OF BOOK OF THE DEAD SUPPLEMENTARY CHAPTER $166^{*}$
}

\author{
By Jan-Michael Dahms, Martin Pehal and Harco Willems
}

As opposed to other studies, the authors approach the interpretation of Book of the Dead supplementary chapter I 66 by taking the introductory part of the text—stating that it has been found 'on the neck of king Ramses II' - at face value. This has the implication that the text was found on the king's mummy, something that could only have happened on one of the several occasions it was reburied after the initial robbings around the end of the New Kingdom. The authors argue that the original text was probably not part of the original tomb contents of Ramses II, but that it was added to it during one of the earliest reburials, and discovered during a later one, probably shortly before the death of Pinodjem II. In this connection they pay special attention to the term $h m=k$, which seems to be used in this text, not to refer to the private papyrus owner, but to the original royal one. This considerably affects the way the textual content can be interpreted. A new transliteration, translation and linguistic commentary are also provided. The analysis of the text illustrates the method of 'sequencing' which seems to prove very useful in reducing the number of interacting characters by disclosing shared structural patterns.

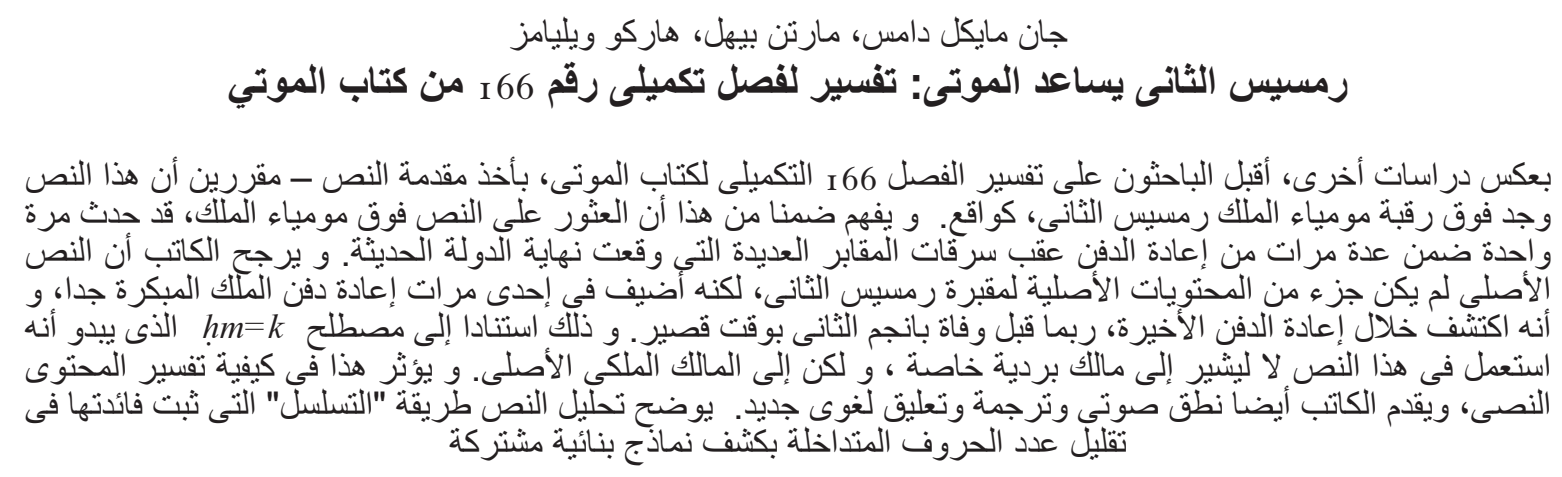

Introduction

Some years ago, the third author of this article selected papyrus Berlin $303 \mathrm{I}$ as reading matter for a course in hieratic. ${ }^{\mathrm{I}}$ It soon appeared that the papyrus contained texts of exceptional interest, and when the two other authors of this paper spent a research

* Martin Pehal expresses his gratitude to the bursary commitee of the Faculty of Arts (Charles University in Prague) for its financial support (project no. VGo79), and also to the Scientific Development Programme of the Charles University in Prague (PRVOUK) no. I3, Rationality in Human Sciences (sub-programme Cultures as World Metaphors). The two other authors would like to thank the Gutenberg Forschungskolleg and the Forschungsschwerpunkt Historische Kulturwissenschaften of the Johannes-Gutenberg-Universität Mainz for financing a research fellowship for Harco Willems and an assistant position for Jan-Michael Dahms, in the context of which this article was written. The authors express their gratitude to David Aston, Dagmar Budde, and Svenja Gülden, who read and criticized a near-final version of this article.

A. Erman (ed.), Hieratische Papyrus aus den Königlichen Museen zu Berlin II. Hymnen an Verschiedene Götter. Zusatzkapitel zum Totenbuch (Leipzig, I905), 48-52. The papyrus has been studied by M. Z. Allam (Papyrus Berlin 303I: Totentexte der 2I. Dynastie mit und ohne Parallelen [Bonn, I 992]). H. Willems is currently preparing a new publication of this document. 
period at Leuven University, parts of the document were jointly discussed again in great detail. The analysis of P. Berlin $303 \mathrm{I} \mathrm{V,} \mathrm{2-VII,} 3$ in particular was rewarding, suggesting a quite unusual case of appropriation of royal status for use by private individuals. Since to our knowledge no comparable case is known, we wish to share our findings with a wider audience.

The Berlin papyrus includes several of the so-called 'chapitres supplémentaires du Livre des Morts', besides other material. These chapters (BD supplementary chapters I 62-I 74) ${ }^{2}$ are in many ways remarkable. Different from most 'normal' BD chapters, they are written in Late Egyptian, and the theology they evoke addresses religious issues that are otherwise hard to find in the Book of the Dead, but that seem to be rooted in late (or post-) New Kingdom Theban temple theology. Another common feature of many of these spells is that a god is frequently referred to by-probably deliberately incomprehensible-'secret names'. In some documents, this group of texts receives an Egyptian label specifying that they are, in fact, an addition to the Book of the Dead. ${ }^{3}$ These documents have been frequently translated and studied, common discussion themes being the place of origin of this group of texts, the supposed Semitic or Nubian origin of the divine names, or the coherence of the group. These issues, however, do not concern us here, and we refer the interested reader to the literature compiled by A. Wüthrich. ${ }^{4}$

The pertinent part of the Berlin papyrus offers a version of supplementary BD chapter i66. Several other variants of this text are known, which are rendered in a synoptic presentation in Allam's book. ${ }^{5}$ This text has frequently been translated, ${ }^{6}$ but it has only to a very limited extent been submitted to an analysis of content. This is what we wish to do here. In section 2 of this article, we will first address the 'title' at the beginning of the document, which describes the origin of the text. Since this part seems to refer to the mummy of Ramses II as the find spot of the text, section 3 will study what is known about the fate of this mummy. This is followed in section 4 by an analysis of the date of composition of the text. This, combined with evidence on the early use of BD chapter I 66 (section 5), offers a startling impression of how BD chapters could be brought into circulation. In section 6 , a designation of the deceased that is frequently used in all versions of BD chapter $\mathrm{I} 66$ will be investigated, as it differs from what is customary elsewhere in the $\mathrm{BD}$, or, for that matter, the funerary literature in general. This is followed in section 7 by a translation and commentary. In section

\footnotetext{
2 Here we must refer to the well known fact that both W. Pleyte, Les chapitres supplémentaires du Livre des Morts (Leyde, I882) and E. Naville, Das ägyptische Todtenbuch der XVIII. bis XX. Dynastie I (Berlin, I886), assigned new BD chapter numbers supplementing those of Lepsius, Das Todtenbuch der Ägypter nach dem hieroglyphischen Papyrus in Turin (Leipzig, I842). In the process the numbers 166-I74 were assigned twice, referring to entirely different texts. We are here using Pleyte's numbering.

3 The chapitres supplémentaires are here designated as 'Spells brought from another scroll in addition to the appearance into the day' (extensively discussed by J. Yoyotte, 'Contribution à l'histoire du chapitre I 62 du Livre des Morts', RdE 29 [1977], I94-200). Since the composition of the group of supplementary chapters varies, while it is uncertain whether the label can apply to all of them, there is discussion over whether it was really a coherent group. This issue does not concern us here, however.

$4 \quad$ A. Wüthrich, Éléments de théologie thébaine: les chapitres supplémentaires du Livre des Morts (SAT i6; Wiesbaden, 20I0). See also the reviews of this book by J. F. Quack, WdO 4I (20 I I), 255-6 I and D. Luft, OLZ Io8 (2013), 78-83.

5 Allam, Papyrus Berlin 3031, 78-132.

6 See for an overview Wüthrich, Éléments de théologie thébaine, 98-I I 5.
} 
8 , this translation will then be analysed making use of the method of 'sequencing'.7 Finally section 9 will give an overall interpretation of BD chapter $\mathrm{r} 66$.

\section{The 'title' to Book of the Dead chapter 166}

Of the known sources, six are preceded by a title.

( I) The Berlin papyrus offers the most complete version, reading 'The scroll found on the neck of king Userma atre Setep<enre>, 1.p.h, in the necropolis.' The title in version $\mathrm{L}_{2}{ }^{8}$ has essentially the same reading, while the first part is missing in variant PI I. 9

(2) Versions $\mathrm{L}_{4}{ }^{\text {Io }}$ and $\mathrm{L}_{5}{ }^{\text {II }}$ have a slightly different version, reading 'The scroll that was found in the time/in the neighbourhood of $(m-h 3 . w)$ King Userma atre in the necropolis'.

(3) In version $L_{3}$, the royal name has been dropped. This version instead reads: 'The scroll that is at the neck of Osiris N.' ${ }^{2}$

As shown in the translation above, variant 2) can be read in different ways. If the noun $h 3 . w$ is read as 'time', it only explains when the scroll was found. However, this might in itself not be a very important piece of information, and it implies a difference of meaning as against I). The alternative of reading $h$ 3.w as 'neighbourhood' may have the greater likelihood, as, just like I), it implies that the original document was found close to the body of a king called Userma atre. ${ }^{\mathrm{I} 3}$ As we will see below, much of the content of the spell can be readily explained if it is assumed this was effectively the case.

The king mentioned in the title is in most papyri called Userma atre, a designation that can apply to several pharaohs. It is generally assumed, however, that Ramses II, the most illustrious bearer of the name, is likely to be referred to. ${ }^{14}$ Remarkably, it has never been pointed out in this connection that one of the earliest sources for BD chapter I66, P. Berlin 303 I, has the reading Userma' atre Setep<enre>, a name string borne by Ramses II and Ramses VII, besides some kings that lived long after the Berlin papyrus had been written, and that are therefore certainly irrelevant. Although it is strictly speaking possible that the name refers to the short-lived Ramses VII, the alternative that our text concerns his famous earlier namesake certainly has the greater likelihood. We therefore accept the current identification of the king as Ramses II. ${ }^{15}$

\footnotetext{
7 For this, see H. Willems, 'The Method of "Sequencing" in Analyzing Egyptian Funerary Texts: The Example of Coffin Texts spells 283 and 296', in S. Bickel (ed.), Ancient Egyptian Funerary Literature: Tackling the Complexity of Texts. Basel, December 9-II, $20 I 0$ (in press).

8 P. Leiden T25 (Pleyte, Les chapitres supplémentaires, pl. I I I for the transcription, see Allam, Papyrus Berlin 303I, 8I).

$9 \quad$ P. Louvre 3 I 72 (W. Spiegelberg, Die ägyptische Sammlung des Museum-Meermanno-Westreenianum im Haag [Strasbourg, I 896], pl. 2B; for the transcription, see Allam, Papyrus Berlin 303I).

Io P. T I A (Pleyte, Les chapitres supplémentaires, pl. I I I; for the transcription, see Allam, Papyrus Berlin $303 I)$. Berlin $303 I$ )

P. Leiden T3 I B (Pleyte, Les chapitres supplémentaires, pl. I I I; for the transcription, see Allam, Papyrus

I2 P. Leiden T30 (Pleyte, Les chapitres supplémentaires, pl. I I I for the transcription, see Allam, Papyrus Berlin $303 I$ ).

I3 The possibility of this translation was not considered by A. Wüthrich (Éléments de théologie thébaine, 6).

${ }_{14}$ E.g. Yoyotte, RdE 29, I97; Wüthrich, Éléments de théologie thébaine, 6; Quack, $W d O{ }_{41},{ }_{5} 8$.

15 Here one might add that name strings of Ramses II often are similar in arrangement to that found in P. Berlin 303 I, whereas in the name of Ramses VII the sign for Amun (belonging to the epithet Meryamun) usually
} 
Several Book of the Dead chapters include postscripts that trace their putative origin to a glorious and distant past and to places of great sanctity. ${ }^{16}$ Thus, BD chapter 64 is said to have been found in al-Ashmūnayn (i.e. probably the temple of Thoth, the god of wisdom and writing) in the time of king Menkaure by prince Djedefhor. Version Ca even attributes the find to the reign of the First Dynasty king Den. ${ }^{17}$ The implication that the text was ancient already at this early date is obviously a rhetoric ploy to enhance its perceived sanctity by placing its origin close to the mythical era when the gods still reigned on earth. However, both the disagreement between the two find descriptions and the fact that the text is not written in Early Dynastic or even Old Egyptian makes it clear that these postscripts are merely legendary accounts. With respect to BD chapter I66, the same opinion has been voiced, although no pertinent evidence was used to support this claim. ${ }^{18}$ Probably the fictitious reputation of this whole category of historiolae was enough to justify scepticism in the present case also. In most other studies, the 'title' of BD chapter $\mathrm{I} 66$ is not analysed at all. No study has ever made the attempt to take the introductory words seriously, and to relate them to the textual content. Contrary to this, we will investigate the consequences for the interpretation of the spell of the assumption that the text is a historically truthful account, or at least pretends to be so. ${ }^{19}$ As we hope to show on the next pages, the date, cultural setting, and social environment in which the earliest extant copies emerge certainly make this an option that merits exploration.

Unlike many other find accounts, the introductory text to BD chapter I 66 does not situate the discovery in a distant past, but at the moment it was found on the mummy of Ramses II. Whether or not this ever really happened is open to discussion, but for the text to have any credibility, it can only have referred to a moment when the royal mummy could have been really seen. ${ }^{20}$ A literal reading of the title implies that knowledge of the chapter was based not only on inspection of the king's tomb, something that we know occasionally happened, ${ }^{21}$ but on direct inspection of his mummy. This would only be possible if all the king's sarcophagi and coffins were opened before the papyrus was discovered. This is unlikely to have happened during routine inspections. It is, however, clear that, in the late Twentieth Dynasty and after, the contents of many royal tombs in the Valley of the Kings were evacuated. On such occasions, a small papyrus containing the text of BD chapter I 66 could well have been found. However, this is not the only possible scenario. Since several royal mummies were reburied several times,

intervenes between Userma atre and Setepenre (J. von Beckerath, Handbuch der ägyptischen Königsnamen [MÄS 49; Mainz, I 999], I 55 and I 73).

i6 See the references in n. 68.

${ }_{17}$ E. Naville, Das ägyptische Todtenbuch der XVIII. bis XX. Dynastie II (Berlin, I 886), I39.

i8 Thus, Wüthrich interprets the title as 'une indication fallacieuse' without further ado (Éléments de théologie thébaine, 7).

${ }_{19}$ The title was already interpreted in this way by N. Reeves, The Complete Valley of the Kings: Tombs and Treasures of Egypt's Greatest Pharaohs (London, I996), 206, though without further analysis of the contents.

20 Even if the text contains an invented find history, this could only have been convincing if the case had some historical likelihood. For the interpretation of the textual content, this makes as little difference as an answer to the question of whether the report of Wenamun was a factual account or a historical romance (see the remarks by A. Egberts, 'The Chronology of the Report of Wenamun', $\mathcal{F} E A 77$ [1 991], 57).

${ }_{21}$ Such an inspection is extensively reported upon in Papyrus Abbott (T. E. Peet, The Great Tomb Robberies of the Twentieth Egyptian Dynasty [Oxford, I930], pl. I-IV). An overview of texts referring to inspections of private tombs in Dayr al-Madina has been collected by K. M. Cooney, 'Changing Burial Practices at the End of the New Kingdom: Defensive Adaptations in Tomb Commissions, Coffin Commissions, Coffin Decoration, and Mummification', $\mathcal{F} A R C E 47$ (201 I), I2, tab. 3. 
it is also conceivable that on one of these occasions the sorely damaged sets of burial equipment of the kings were replenished by new funerary gifts, which accordingly would not derive from the original royal burial. Both options (i.e. the papyrus with BD chapter 166 formed part of the original burial equipment of Ramses II, or it was a later addition) should be seriously considered.

It is also important to note that the Amun priests from Karnak were deeply involved in moving the New Kingdom royal mummies from one cachette to the other, because, as will be shown below, the first attestations of BD chapter $\mathrm{r} 66$ appear in burials precisely of these priests. These date to the second half of the Twenty-First Dynasty, at the most ninety years after the text was discovered if it was found at the end of the Twentieth Dynasty. Moreover, the text was then only just over a century old. Clearly, there is no pretence that the text was very old. Instead, it establishes a link with the mummy of Ramses II, which we know the Amun priests had a keen interest in, moving it about several times in the century following the tomb robberies (see below). While this does not prove BD chapter i 66 was really found on the king's mummy, it certainly could have been.

\section{The post-mortem fate of Ramses II}

Fortunately, the mummy of Ramses II has been found, and dockets on his coffin combined with analysis of the find circumstances render possible a reconstruction of his post-mortem fate. This offers a possibility to confront the content of the Book of the Dead spell with archaeological realia. The mummy was discovered in the royal cachette in TT 320 , but it is clear it had not been brought there immediately from the original royal tomb in the Valley of the Kings. Recent study of all the pertinent evidence by E. Graefe and G. Belova, supplemented by a critical re-evaluation by D. Aston, provides a detailed insight of the sequence of events:

(A) Year 6 of Herihor: According to a hieratic docket on the coffin of Ramses II, the king's mummy was reburied in year 6 of the king, high priest and general Herihor, probably early in the Twenty-First Dynasty. ${ }^{22}$ Although this was definitely an original royal coffin, it had been stripped of all of its gold, it was painted over in yellow, and provided with the hieratic docket, over which the names of Ramses II were carelessly written in large hieroglyphs. Daressy believes that the coffin had not originally belonged to Ramses II, but to another king. If this is true, the mummy of Ramses II must have been taken out of its original case before being reburied in the new one. But even if Daressy is wrong, ${ }^{23}$ and this was originally the coffin of Ramses II himself, the mummy must have been temporarily removed from the coffin, because otherwise it would have been impossible to strip off the gold and other decoration. This may have been done by the priests themselves or by the tomb robbers preceding them. ${ }^{24}$ This is important, as

22 Cairo CG 61020; see G. Daressy, Cercueils des cachettes royales (Le Caire, I909), 32-34; pl. XXXXII; XXIII. For a translation of the text, see R. Ritner, The Libyan Anarchy: Inscriptions from Egypt's Third Intermediate Period (Atlanta, 2009), I о0. On the issue of this being a regnal year of Herihor, see G. P. F. Broekman, 'The Theban High-Priestly Succession in the First Half of the Twenty-First Dynasty', $\mathcal{F} E A 98$ (2012), I 98, with a reappraisal of the literature.

${ }_{23}$ As is apparently D. Aston's interpretation, see his 'Two Osiris Figures of the Third Intermediate Period', $\mathcal{F E A} 77$ ( 1991), 98.

${ }^{24}$ It now seems more likely that the Amun priesthood itself was responsible for pillaging the royal tombs 
it may provide a date for the moment when the papyrus attached to the neck of Ramses II was found.

The record of his reburial is unfortunately riddled with lacunae, but in this part of the text one can still read a reference to 'numerous effective shabtis' (lines 6-7). This may not be entirely irrelevant to our analysis, since BD chapter I 66 includes an important section concerning shabtis. Based on entirely different indications, it has moreover been argued that, during their reburial in the Twenty-First Dynasty, the Ramesside kings were supplied with newly made funerary equipment, including, in the case of Ramses II, shabtis. In another documented case, a shabti that had been part of the original burial equipment of Ramses II was converted into an Osiris figure of a type common in the Twenty-First Dynasty. ${ }^{25}$ Against this background, the possibility of other funerary equipment (for instance a papyrus with BD chapter I66) being placed on the king's mummy may be considered a distinct possibility. The mummies of Ramses I and Seti I were reburied likewise, and an inscription explicitly dates the reburial of the latter explicitly to Herihor's year $6 .{ }^{26}$ The dockets, badly legible in parts, contain no indications where the reburials took place. It might have been in the original tombs (thus $\mathrm{KV} 7$ for Ramses II).

(B) Year I 5, 4 3h.t, day 6 of the high priest of Amun Pinodjem I: a note on one of the wrappings of the mummy of Ramses II details that on this day it was brought in order to 'renew' (whm) and bury it in the tomb of Seti I (KV I 7). ${ }^{27}$ The reference to 'renewal' and the fact that the record was found on a mummy wrapping of Ramses II suggests that prior to its reburial, the mummy had been at least partially unwrapped. This document provides fewer details than the docket pertaining to phase A. It is possible, but by no means certain, that the funerary equipment perhaps newly added by Herihor accompanied the mummy to its new place of burial.

(C) Year Io, 4 pr.t, day I 7 of king Siamun: Dockets on the coffins of Ramses I and II and of Seti I document that they were removed on this day from the tomb of Seti I to a tomb designated as 'the $k 3 . y$ of Inhapy, in which Amenhotep I lies' ${ }^{28}$ According to Belova and Graefe this was the tomb of Amenhotep I in Dirā Abū al-Naj'. However, it is far more likely that 'the $k 3 . y$ of Inhapy' was in fact tomb KV $39 .{ }^{29}$

(D) Year I o, 4 pr.t, day 20 of king Siamun: The mummies of Seti I and Ramses II (and probably that of Ramses I as well) were laid to rest in 'the House of Eternity of Amenhotep', a place identified by Graefe and Belova and Aston with the tomb of Amenhotep I. ${ }^{3 \circ}$ In recent years D. Polz's idea that this is tomb K93. I I in the Dirā Abū al-Naj' has gained wide acceptance, but in a re-evaluation of Aston's article, Dodson

and thus that they mostly were the tomb robbers; see Reeves, The Complete Valley of the Kings, I94-207; K. Jansen-Winkeln, 'Die Plünderung der Königsgräber des Neuen Reichs', $Z \ddot{A} S$ I 22 (1995), 62-78.

25 Aston, $\mathscr{F} E A$ 77, 95-9; Reeves, The Complete Valley of the Kings, 206.

26 For the sequence of events, see E. Graefe and G. Belova, The Royal Cachette TT 320: A Re-Examination (Cairo, 2010), 46-59; D. Aston, 'TT 320 and the $k 3 y$ of Queen Inhapy - a Reconstruction Based on Ceramic Evidence', GM 236 (2013), 9 .

27 K. Jansen-Winkeln, Inschriften der Spätzeit I: Die 2I. Dynastie (Wiesbaden, 2007), 22-3 (36).

28 For the dates, which differ from those in Daressy's publication (Cercueils des cachettes royales, 27; 30-I;

33): K. Jansen-Winkeln, Inschriften der Spätzeit I, I I4-I 7 [A-dockets]).

29 Aston, GM 236, 7-20.

$3^{\circ}$ Jansen-Winkeln, Inschriften der Spätzeit I, I I 6-I 7 (B-dockets); Graefe, and Belova, The Royal Cachette TT 320, 46-59; Aston, GM 236, 9. 
has recently suggested that the old hypothesis that the tomb of Amenhotep I is actually tomb AN B on top of the Dirā Abū al-Naj ' has the greater likelihood. ${ }^{3}$

On exactly the same day the three kings were reburied, probably in this tomb, the high priest of Amun Pinodjem II was buried in T'T 320 . According to two graffiti inside that tomb, ${ }^{32}$ his wife Nesikhons had already been interred there five years before. ${ }^{33}$ The latter circumstance suggests that the creation of the family tomb of the Amun priests in TT 320 was planned well ahead of Pinodjem's death.

In fact, the history of use of the tomb goes back even further and suggests that the creation of the royal cache and of the tomb of the Amun clergy there went hand in hand. D. Aston has plausibly argued that TT 320 was originally the tomb of the early Eighteenth Dynasty queen Ahmose Nefertari, whose funerary equipment was found there. ${ }^{34}$ Between year 8 of Psusennes I and year 5 of Siamun, numerous late Seventeenth and early Eighteenth Dynasty kings, queens and other royals were then transferred from their original burials in the Dirā Abū al-Naj' to TT $320 .{ }^{35}$ Thus the tomb of Ahmose Nefertari was first converted into a royal cachette early in the TwentyFirst Dynasty, and then used from Siamun's year 5 onwards as a family tomb for the high priest family of Amun. The first of the latter were the lady Nesikhons, followed in year Io by her husband Pinodjem II, whose burial, as mentioned, coincided with the third reburial of Ramses I, Seti I, and Ramses II in the tomb of Amenhotep I.

E) Reign of Sheshonq I or later: circumstantial evidence discussed by D. Aston shows that Amun priests were still being buried in TT 320 in or after the reign of Sheshonq I, witness the burial of Djedptahefankh. ${ }^{36}$ After this time, several other coffins were placed nearest the entrance of the tomb, and in view of this position these must have been the latest burials to have been placed there. This group includes the coffined remains of Seti I, and Aston assumes that the other members of the 'Inhapi group', i.e. Ramses I and II were placed in TT 320 at the same time, ${ }^{37}$ even though the confused evidence on the find context makes a final verdict on this point impossible.

Placing royal mummies in cachettes is often considered an emergency measure intended for safeguarding the endangered mortal remains of the New Kingdom pharaohs. However, from this perspective it makes poor sense that some kings were reburied several times, and often in such a way that they had to be moved over large distances. The transportation of Ramses I, Seti I and Ramses II from KV 39 to the tomb of Amenemhotep I, and later from there to TT 320, must have been visible from afar and can hardly have remained secret. From a security perspective this policy is therefore somewhat perplexing. One wonders whether safety was the only, or even the most important consideration. If the Amun priests themselves were actually

${ }^{31} \quad$ D. Polz, Der Beginn des Neuen Reiches: Zur Vorgeschichte einer Zeitenwende (Sonderschrift DAIK $3 \mathrm{I}$; Berlin, 2007), I72-97; A. Dodson, 'On the Burials and Reburials of Ahmose I and Amenhotep I', GM 238 (2013), I $9-24$.

$3^{2}$ Jansen-Winkeln, Inschriften der Spätzeit I, I4I-2 (33).

Jansen-Winkeln, Inschriften der Spätzeit I, I I 8 (20); Graefe and Belova, The Royal Cachette TT 320 , $46-8$.

Aston, GM 236, I0-I3; this is based to a large extent on an article by C. Sheikholeslami, 'A Lost Papyrus and the Royal Cache in TT 320 before I 88I', in Z. Hawass, K. A. Daoud, and S. Abd El-Fattah (eds), The Realm of the Pharaohs: Essays in Honour of Tohfa Handoussa I (Cairo, 2008), 377-400.

35 Aston, $G M 236$, I4.

${ }_{36}$ Aston, $G M 236,8$, I4.

37 Aston, $G M 236$, 14. 
responsible for removing the valuables from the royal tombs (see n.24) this is in fact highly unlikely. However, this does not lessen the likelihood that they were portraying themselves as pious successors taking great pains to ensure the afterlife of the dead kings.

The previous account shows that reburial of New Kingdom royals was an ongoing process that began in the early part of the Twenty-First Dynasty and continued into the Twenty-Second. Moreover, in connection with this, funerary equipment was adapted or freshly produced for some kings, including Ramses II. The choice of place for the reburials often seems not to have been determined simply by expediency. It is unclear whether the mummies of Ramses I and II and of Seti I were brought to other tombs on their first reburial (A), although this seems unlikely. We have no idea why the second reburial discussed here was in the tomb of Seti I (B). Perhaps, in this case expediency was the reason. However, the next steps seem to have been determined by a desire to establish a link between the Amun priesthood, the early Eighteenth Dynasty kings, and the early Ramessides. These latter were first transported to the tomb of the early Eighteenth Dynasty queen Inhapy, 'where Amenhotep I was resting' (KV 39) (C). Three days later (D), the high priest Pinodjem II was buried in the tomb of the mother of Amenhotep I, Ahmose Nefertari (TT 320), where numerous early Eighteenth Dynasty royals had already been brought together in the first half of the Twenty-First Dynasty. On the same day, the early Ramesside kings' mummies were brought from KV 39, where Amenhotep I was at that moment also located, to what was probably Amenhotep's original tomb. After later priest burials had been added in TT 320 , Ramses I, Seti I and Ramses II were finally brought to TT 320 as well during or after the reign of Sheshonq I (E).

Looked at this way, the creation of the royal cachettes seems to have been a dynamic process in which the dead priests came to be intimately linked to the New Kingdom royals. The choice of place, with its apparent preference for tombs linked to Amenhotep I and Ahmose Nefertari, is probably not coincidental. Already in the New Kingdom, both had evolved into a kind of patron saints in the Theban necropolis, and they also had a shared cult. ${ }^{8}$ This cult persisted into the Twenty-First Dynasty, when it is particularly strongly in evidence in the decoration of the coffins of the Amun priests. ${ }^{39}$ A. von Lieven has argued that Amenhotep may have enjoyed a particular popularity among the Amun priests as one of the great builders at Karnak. As she points out, some evidence in this temple also seems to portray him as a son of Amun. ${ }^{40}$ She further argues that his iconography in the coffins of the Twenty-First Dynasty differs from that in earlier sources: he now appears in the form of a mummy. Von Lieven hesitantly speculates that this iconography may be related to the reburial of Amenhotep's mummy. She also adduces extensive evidence for a tendency to increasingly portray the dead Amenhotep I as an Osiris, thus transforming him into a funerary deity. ${ }^{4 \mathrm{I}}$

\footnotetext{
$3^{8} \quad$ G. Hollender, Amenophis I. und Ahmes Nefertari: Untersuchungen zur Entwicklung ihres posthumen Kultes anhand der Privatfelsgräber der thebanischen Nekropole (Sonderschrift DAIK 23; Berlin, 2009); review by A. von Lieven, $W d O 40$ (2010), I $21-30$.

39 R. van Walsem, The Coffin of Djedmonthuiufankh in the National Museum of Antiquities at Leiden (Leiden, I 997), 3 I 7-25, colour pl. Id; A. von Lieven, 'Kleine Beiträge zur Vergöttlichung Amenophis' I.: II. Der Amenophis-Kult nach Ende des Neuen Reiches', $Z \ddot{A} S$ I 28 (200I), 4I-64.

$40 \quad$ von Lieven, $Z \ddot{A} S$ I $28,52$.

4I von Lieven, $Z \ddot{A} S$ г 28, 57-64.
} 
The cult of the royal ancestors Ahmose Nefertari and Amenhotep I thus seems to have formed the context within which the early Ramesside kings were reburied..$^{42}$ It cannot be determined with any certainty during which of the three reburials the papyrus carrying BD chapter I 66 was found, but since the mummy was certainly taken out of its coffin temporarily in year 6 of Herihor, one option would be that the papyrus was discovered then. In this case, it formed part of the burial equipment of Ramses II, and it must have been written towards the end of his life or a short while after. Alternatively, Herihor might have added the document during phase A, and the text was then written in his time, then discovered during the preparations for phase B. A third option is that the papyrus was added in the time of Pinodjem I when the mummy of Ramses II was rewrapped in connection with phase $\mathrm{B}$ and rediscovered when the mummies were removed again in connection with the preparations for phases $\mathrm{C}$ and $\mathrm{D}$. These options are of some relevance to the interpretation of BD chapter 166.

\section{The date of composition of the text}

Here the linguistic register of $\mathrm{BD}$ chapter $\mathrm{I} 66$ merits consideration. It is remarkable in that it, like all other 'chapitres supplémentaires', includes many grammatical features that are characteristic of Late Egyptian. Wüthrich argues that the Book of the Dead is largely devoid of Late Egyptian influences, and that the present group of chapters must accordingly have been composed at a later point in time than the rest of the corpus. For our text she believes that this would have happened 'au plus tôt durant l'époque ramesside'. ${ }^{43}$ Since the earliest attestations of the text date to the second half of the Twenty-First Dynasty, this suggests a date of origin between the early Nineteenth Dynasty and that latter point in time. In his review of Wüthrich's book, J. F. Quack, however, dated the whole group of the supplementary chapters to the New Kingdom: 'eher spätere I 8. oder I 9. Dynastie als 20. Dynastie.'44 Unfortunately, he did not specify the linguistic arguments for this, but in a written comment to $\mathrm{H}$. Willems (dated $2 \mathrm{I}$ November 2012) he writes that, as regards the date of BD chapter I66, the only feature of chronological relevance is the occurrence of the negative aorist $b w s \underline{d m}=f$ in P. Berlin 303 I, VI, I. The fact that later Late Egyptian replaces this form by $b w j r j=f s \underline{d m}$ would suggest a date at in the early Ramesside period at the latest. Although most grammars express the same view on the evolution of the verb form, much later forms of the negative aorist $b w s \underline{d} m=f(<\operatorname{MEg} n s \underline{d} m . n=f)$ postdating the Nineteenth Dynasty are, however, by no means rare. Examples still occur in Madinnat Habū (reign of Ramses III), ${ }^{45}$ in a hymn to Ramses VI and VII datable to the reign of the latter king; ${ }^{46}$ in numerous examples in P. Lansing, which Gardiner has dated to the late Twentieth Dynasty, ${ }^{47}$ and in P. Chester Beatty $\mathrm{I},{ }^{48}$ datable between Ramses V and XI.

\footnotetext{
${ }^{42}$ Note that the name of an Amenhotep may also occur in the docket of year 6 of Herihor, line 3 (see $n$. 22).

43 Wüthrich, Éléments de théologie thébaine, I0-1 5; citation from p. I3.

44 Quack, $W d O_{41}, 255^{-6 .}$

$\mathrm{K} R I \mathrm{~V}, \mathrm{I} 3,7 ; \mathrm{I} 6, \mathrm{I} 5 ; 28, \mathrm{I}-2$.

46 P. Turin 54013, rt. 21,7: V. Condon, Seven Royal Hymns of the Ramesside Period: Papyrus Turin CG 5403 I (MÄS 37; Berlin, I 978 ), ro and 80.

47 A. Gardiner, Late Egyptian Miscellanies (Bruxelles, I 937), XVIII; e.g. rt. VI,5, 6, 8-9, VII, I, IX,4,9; XI,2; III,7-9

${ }_{48}$ A. Gardiner, The Library of A. Chester Beatty (London, I 93 I), pl. XIV; rt I4, I 2.
} 
Other examples occur in versions of the Teachings of Ani. One could object that these documents are simply reproductions of an earlier base text, but since its editor, Quack, has stressed the dynamic form of transmission in this group of teachings, this is not a grave objection. ${ }^{49}$ Examples occur in the version of Papyrus Louvre 30144 , I,4; II,4, datable to the mid-Twentieth Dynasty ${ }^{50}$ and in P. Bulaq 4, rt. I7, I7; I 8, I; 2I,9-IO; etc., datable to the Twenty-First Dynasty. ${ }^{51}$ O. Louvre 698, 6 contains a further example. This is the letter of Butehamun to Ikhtay's coffin, datable to the late Twentieth or early Twenty-First Dynasty. ${ }^{52}$ Jansen-Winkeln even gives an example from the Thirtieth Dynasty. ${ }^{53}$ The upshot of this overview is that the form of the negative aorist does not force us to date the text in the early Ramesside Period. A date around or after the end of the New Kingdom is by no means impossible.

Quack also criticized Wüthrich's somewhat schematic approach to dating religious texts based on historical grammar. ${ }^{54} \mathrm{He}$ seems to suggest, based on A. von Lieven's detailed methodological study of the principles of dating by linguistic features, ${ }^{55}$ that there would be no problem with attributing funerary texts written in Late Egyptian to a date relatively early in the New Kingdom. This would be crucial to our interpretation of the text. Von Lieven argued that, generally speaking, Egyptian scribes were hardly familiar with earlier stages of the language: if a later text reproduces a much earlier stage of the language correctly, she argues, this is due mostly to copying earlier texts. As soon as the scribes begin to write new texts, she argues, recent features immediately manifested themselves. Quack apparently assumes that this would also be possible for the chapitres supplémentaires. In the case of BD chapter I66, which claims to derive from a burial of an early Ramesside king, this could be taken as implying that royal funerary texts written in Late Egyptian could date to this early period.

However, against Quack and von Lieven, K. Jansen-Winkeln has convincingly argued that Amduat, and probably the other New Kingdom guides to the netherworld as well, were newly composed in the New Kingdom and display a rather keen knowledge on the part of the scribes of many features of earlier Egyptian, which they tried to imitate..$^{6}$ This strongly suggests that earlier forms of Egyptian were preferred for the royal tombs. These kings were also provided with Book of the Dead spells, which, on the whole, are written in more or less correct classical Egyptian. Even though von Lieven's study raises important points concerning the mechanisms of transmission of literary and religious texts, neither she nor Quack have adduced examples of funerary compositions in New Kingdom royal tombs that are (like BD chapter I 66) fully written

49 J. Quack, Die Lehren des Ani: Ein neuägyptischer Weisheitstext in seinem kulturellen Umfeld (OBO I4I; Freiburg, 1 994), I3-23.

50 Quack, Die Lehren des Ani, го.

${ }^{51} \quad$ Quack, Die Lehren des Ani, 7-8.

$5^{2}$ HO I, pl. 80/8Ia; P. J. Frandsen, 'The Letter to Ikhtay's Coffin: O. Louvre inv. No. 698', in R. J. Demarée and A. Egberts (eds), Village Voices: Proceedings of the Symposium 'Texts from Deir el-Medina and their Interpretation. Leiden, May 3I-Fune I, I99I (CNWS Publication I3; Leiden, I992), 3 I-49.

$53 \quad$ K. Jansen-Winkeln, Biographische und religiöse Inschriften der Spätzeit aus dem Ägyptischen Museum Kairo I (ÄAT 45; Wiesbaden, 200I), 85, n. 40 (Thirtieth Dynasty).

54 Quack, $W_{4} \mathrm{O}_{41}$, 255-6.

55 A. von Lieven, Grundriss des Laufes der Sterne: Das sogenannte Nutbuch (CNI Pubications 31: Copenhagen, 2007), 223-54; see recently also J. Quack, 'Von der Vielfalt der ägyptischen Sprache', ZÄS I40 (2013), 36-53.

${ }_{56}$ K. Jansen-Winkeln, 'Zu Sprache und Datierung des Amduat', $\mathcal{F} E 9$ 98 (2012), 87-ıо6. 
in Late Egyptian. ${ }^{57}$ In private tombs, the situation seems to be the same, since here, one mainly finds Book of the Dead material.

It would therefore strike one as highly unusual if a papyrus attached to the body of Ramses II would have been written in Late Egyptian. By contrast, in the Third Intermediate Period, even funerary texts could be written in Late Egyptian-witness, for example, the Nesikhons Decree. ${ }^{5}$ Culturally, therefore, we think that the text is more likely to date to a period in (or shortly before) the Third Intermediate Period than to the time of Ramses II.

\section{The early attestations of Book of the Dead chapter 166}

The earliest attestations of BD chapter 166 are all of Theban origin, and all date to the Twenty-First Dynasty. ${ }^{59}$ All except papyrus Berlin 303 I were found, not on Book of the Dead papyri, but on small sheets of papyrus only containing this spell. Wüthrich has compiled the evidence concerning these early documents. A major group derives from the Bāb al-Gasūs cachette, where Theban Amun priests were buried. As she points out, many papyri were found within the mummy bandages, at the neck of the corpse, but also elsewhere. Secondly, several instances are of unknown origin, but belonged to members of the Theban Amun clergy. This is possibly also the case for the owner of papyrus Berlin 303 I, who was of Theban origin. According to Wüthrich's convincing account, the mummies concerned date to the period of office of Pinodjem II at the earliest. $^{60}$

57 Of course this does not rule out that texts in royal tombs may occasionally feature 'Late Egyptianisms'.

$5^{8}$ B. Gunn, 'The Decree of Amonrasonther for Neskhons', JEA 4I (I955), 83-I05; Jansen-Winkeln, Inschriften der Spätzeit I, I30-4I (32).

59 Two papyri have been dated to an earlier period. I) Allam, Papyrus Berlin 303I, pl. XI-XII, dates P. Louvre $3 \mathrm{I} 72$ to the period between the Nineteenth and the Twentieth Dynasties. His only comment to this ('Vgl. pKairo 58059 (19. Dyn.) = Bakir Epistolography, pl. 9’) is rather enigmatic, and affords no support for this date. Probably his dating goes back to W. Spiegelberg's unsubstantiated remark that this papyrus can be attributed to the Nineteenth Dynasty (Die ägyptische Sammlung des Museum-Meermanno-Westreenianum, I4-I 5, n. 2). However, the hieratic of the small fragment published in pl. IIB would allow for a date in the Twenty-First Dynasty (e.g. the signs A26, D28; E23; G47; V3I; cf. U. Verhoeven, Untersuchungen zur späthieratischen Buchschrift [OLA 99; Leuven, 200I]); 2) In the publication of P. Cairo 58005, W. Golénischeff dates this document, probably on the basis of his assessment of the palaeography, to the end of the Twentieth or the early Twenty-First Dynasty (Papyrus hiératiques [CG 5800I-58036], [Le Caire, I927], I6-I8). The papyrus was found on a mummy that was later unwrapped and on which a set of mummy braces (Cairo JdE 35408) was then found, which according to G. Daressy carried the name of Ramses XI ('Procès-verbal d'ouverture de la momie $\mathrm{N}^{\circ} 29707$ ', $A S A E 3$ [1902], I 5 I-4; Daressy, 'Les cercueils des prêtres d'Amon', ASAE 8 [I 907], 29). On this basis, the papyrus is often dated to the same reign or a bit later (R. Caminos, 'Fragments of the Book of the Dead on Linen', $\mathscr{F} E A 5_{5} 6$ [1970], i 23, n. 2; A. de Caluwe, Un Livre des Morts sur bandelette de momie [BAe XVIII; Bruxelles, I 99I], XVI; H. Kockelmann, Untersuchungen zu den späten Totenbuchhandschriften auf Mumienbinden II [Wiesbaden, 2008], 218). This would make P. Cairo 58005 by far the oldest attestation. However, it was found in the Bāb al-Gasūs cachette, which is generally dated to an advanced date in the Twenty-First Dynasty (A. Niwinski, 'The Bab el-Gasus Tomb and the Royal Cache in Deir el-Bahari', $\mathscr{F E A ~ 7 0}$ [1984], 73-8I). Although some major arguments of Niwinski were recently undermined in D. Aston's study of TT 320, Aston still supports a date in the late Twenty-First Dynasty based on coffin typology (D. Aston, Burial Assemblages of Dynasty 2I-25: Chronology - Typology - Developments [ÖAW Denkschriften LVI; Wien, 2009], I79). According to him, Daressy must have misread the cartouche. The present authors would suggest, in view of the keen interest of the Amun priests in the Ramesside kings, that it could also be a piece taken from a Ramesside tomb. In this respect, it should be noted that it was apparently not uncommon in the Twenty-First Dynasty to produce coffins from planks taken from earlier coffins from the Ramesside period or to take over entire coffins (Cooney, $\mathcal{F A R C E ~ 4 7 , 3 1 - 6 ; ~ A . ~ B e t t u m , ~ F a c e s ~ w i t h i n ~ F a c e s : ~ T h e ~}$ Symbolic Function of Nested Yellow Coffins in Ancient Egypt [PhD Thesis, University of Oslo; Oslo, 2013], 202-3, citing further literature).

60 Wüthrich, Éléments de théologie thébaine, roo-3. 
This date is highly interesting in connection with the conclusions of the preceding section. There, we saw that, after the death of Pinodjem II, the mummies of Ramses I and II and of Seti I were removed from Seti's tomb to the ' $k 3 y$ of Inhapy' (KV 39) and, three days later, to the tomb of Amenhotep I. Since this latter reburial took place on the same day as Pinodjem's burial, it is clear that the Amun priesthood somehow saw a symbolic connection between the post-mortem fate of one of their own dead and those of the illustrious Nineteenth Dynasty kings. In roughly the same period, other members of the Amun priesthood began to be buried with small papyri containing a version of $\mathrm{BD}$ chapter $\mathrm{I} 66$. Interestingly, an important part of this text deals with shabtis, while the Herihor docket on the coffin of Ramses II explicitly refers to a high number of such funerary statuettes in the damaged passage dealing with the king's first reburial (A). Possibly, the shabtis were transferred to KV I 7 during the second reburial (B), and when his mummy was taken out of the Seti tomb during the reign of Siamun (C) the shabtis may also have been remarked upon. One wonders whether there is a connection between the two observations.

Our evidence proves that all of the early non-royal users of BD chapter I 66 were Amun priests from Karnak, precisely the group of people also involved in reburying their own relatives and New Kingdom kings in cachettes. This suggests that the document, when discovered (under Herihor [A], Pinodjem I [B] or, more probably, Siamun $[\mathrm{C}]$ ), raised such an interest among the Amun priests that they kept it separate, and that they or their descendants later used it for their own purposes.

This procedure is not unfamiliar to Egyptologists. In the same period we can see that extracts from the Books of the Netherworld, which are frequently attested in New Kingdom royal tombs, now also make their appearance in private tombs in the form of the so-called 'mythological papyri' ${ }^{6}{ }^{6}$ The same procedure has often been argued to have been followed for earlier funerary compositions. Even though it now seems unjustified to call this a 'democratization' of royal funerary texts, ${ }^{62}$ it is true that Middle Kingdom private persons often deploy the same funerary texts on their coffins as are found in the Old Kingdom royal pyramids. The process is often understood (although perhaps unjustifiably) as an usurpation of originally royal texts by non-royals, the king's name being replaced by that of the private individual concerned. It would not strike one as completely unusual if in an originally royal text (as BD chapter I 66 evidently was, or at least purported to be) the royal name would have been likewise replaced by that of a private individual. However, in the present case, the matter is more complicated.

It is true that in all known versions of BD chapter I 66 the owner is referred to by his or her personal name. However, on repeated occasions this chapter also uses the vocative $h m=k$, 'your Majesty'. This designation has thus far not been specifically commented upon. It seems that most translators tacitly assume that this is just an alternative designation of the deceased. Before embarking on an analysis of the textual content, it is necessary first to investigate how likely this point of view is.

61 A. Niwinski, Studies on the Illustrated Theban Funerary Papyri of the IIth and Ioth Centuries B.C. (OBO 86; Freiburg, I989).

62 H. Willems, Les Textes des Sarcophages et la démocratie: Éléments d'une histoire culturelle du Moyen Empire égyptien. Quatre conférences présentées à l'Ecole Pratique des Hautes Etudes. Section des Sciences Religieuses. Mai 2006 (Paris, 2008). 


\section{The expression $\mathrm{hm}$ in the funerary texts}

The ancient Egyptians used the term $h m$ mainly outside funerary texts. Thus, in the Old Kingdom, it did not occur in the Pyramid texts, and in private tombs, admittedly a funerary context, it appears in descriptions of events during which the king was still alive. ${ }^{63}$ Goedicke suggests that the appellation $h \mathrm{hm}$ occurs when the king as a physical, active person is referred to or where there exists a personal relationship with him and the tomb owner, as opposed to nsw.t, which would designate the king in the general office of the pharaoh. ${ }^{64}$ Although the 'colloquial' translation for $h m$ is 'Majesty', many authors have suggested a similarly physical etymology like 'body' or 'impersonation' for the word. ${ }^{6} 5$ The rare instances where the word is used in polite reference to highplaced non-royals have been similarly explained. ${ }^{66}$

An overview of the attestations of $h m$ in the Wörterbuch and the TLA shows that only a few references belong to funerary literature. ${ }^{67}$ Inasmuch as BD chapter $\mathrm{I} 66$ is part of the Book of the Dead it is useful to have a look at the different attestations of $\mathrm{hm}$ in the Book of the Dead and the prior funerary texts from the Coffin Texts. In all these texts one can find only two ways in which the term $h \mathrm{~m}$ is used: it refers either to the king or to a god. The references to the king are generally found in postscripts that describe how the text was found. ${ }^{68}$ The references to a god are usually found in

63 E. Windus-Staginski, Der ägyptische König im Alten Reich: Terminologie und Phraseologie (Philippika I4; Wiesbaden, 2006), 247; Windus-Staginski, 'Einige Anmerkungen zu njswt und hm im Alten Reich', in C.-B. Arnst (ed.), Begegnungen: Antike Kulturen im Niltal. Festgabe für Erika Endesfelder, Karl-Heinz Priese, Walter Friedrich Reineke und Steffen Wenig (Leipzig, 200I), 466; G. J. Shaw, 'The Meaning of the Phrase $m$ hm n stp-s3', $\mathcal{F E A ~} 96$ (2010), I 79 .

${ }_{64}^{64}$ H. Goedicke, Die Stellung des Königs im Alten Reich (ÄA 2; Wiesbaden, I 960), 52; 68. He was followed in this by many others: T. G. H. James, review of Goedicke, Stellung, $\mathcal{F} E A 47$ ( 1961), г66-8; Shaw, $\mathcal{F E A ~ 9 6 , ~ I 7 5 - ~}$ 90; Windus-Staginsky, Der ägyptische König, I65-206. In support of Goedicke's interpretation, E. Blumenthal, Untersuchungen zum ägyptischen Königtum des Mittleren Reiches (ASAW, 6I/r; Berlin, 1970), 23), links the term $h m$ to dynamic constructions ( $s d m=f, s d m . n=f$, relative forms, subjunctive), whereas nsw.t is connected with static constructions (nominal sentences, genitives in titles, names of buildings, technical terminology, infinitive, etc.). According to J. Omlin, $h m$ in the Middle Kingdom designated the king in his interaction with people (as army commander, head of the state bureaucratic apparatus) and nsw.t as the performer of priestly duties (Amenemhet I. und Sesostris I.: Die Begründer der XII. Dynastie [Heidelberg, I962], 107-8).

65 J. Spiegel, 'Die Grundbedeutung des Stammes hm', ZÄS 75 (I939), I I 2-2 I; H. Frankfort, Kingship and the Gods (Chicago, I 978), 45; J. von Beckerath, Handbuch der ägyptischen Königsnamen (MÄS 49; München, I 999), 32; J. P. Allen, Middle Egyptian: An Introduction to the Language and Culture of Hieroglyphs (Cambridge, 2000), 3 I-32; Shaw, $\mathcal{F E A ~} 96$ (2010), I 76-7. In reaction to Spiegel's article, A. H. Gardiner objected that in no case is this word determined by the flesh sign. He rather suggests that the term was used to refrain from mentioning the name of the king directly for reasons of humility (Gardiner, 'The Word $h m$ in "His Majesty" and the like', $\mathscr{F} E A$ 29 [1943], 79; followed by W. Barta, 'Königsbezeichnung' LÄ III, 477-8I). Recently Hoffmann also disagreed with the interpretation of $h m$ as the physical body, preferring to regard it as a form of authority which was then delegated to subordinates all the way down to the 'servants/slaves' (T. Hoffmann, 'Majestät und Diener - Zur Dialektik des Begriffes h̆m', Z̈̈S г 28 [2001], г г 6-32). Contra, see Windus-Staginski, Der ägyptische König im Alten Reich, 193. She doubts whether we should connect the word $h m$, 'servant/slave', with $h m$ connected to the king (Windus-Staginski, in C.-B. Arnst [ed.], Begegnungen: Antike Kulturen im Niltal, 467).

66 K. Baer, 'A Deed of Endowment in a Letter of the Time of Ppjj I?', ZÄS 93 ( I 966), 5, n. 1.

67 Some sources are texts originally used in temple cult that were secondarily given a funerary function: the 'cérémonial de glorification d'Osiris' (J.-Cl. Goyon, Le Papyrus d'Imouthès Fils de Psintaês [New York, I 999], 49-62) and the 'cérémonial pour faire sortir Sokaris (Goyon, 'Le cérémonial pour faire sortir Sokaris [Papyrus Louvre I. 3079, col. II2-I I4]', $R d E$ 20 [1968], 63-96, and specifically 77 for the classification as a temple liturgy; F. Feder, 'Die verschiedenen Redaktionen des "Rituals des Herausbringens von Sokar aus dem SchetaitHeiligtum”', in L. Gabolde (ed.), Hommages à Fean-Claude Goyon: Offerts pour son yoe anniversaire [BdE I43; Le Caire, 2008], I 5 I-64).

68 BD chapter 64: A text discovered by prince Dedefhor in the time of the $h m$ of Menkaure (G. Lapp, 'Die prt-m-hrw-Sprüche [Tb 2, 64-72] [TbT 7; Basel, 201 I], I 53b/pL6, pL2, pBri, pKrı); for the Nachschrift of BD chapter 64, see D. Wildung, Die Rolle ägyptischer Könige im Bewusstsein ihrer Nachwelt: Posthume Quellen über 
contexts where the gods are indirectly praised or directly addressed. The designation as $h m$ is mainly used for Osiris, the sun god and Thoth, but occasionally for other gods like Shu or Seth. ${ }^{69}$

There is only one funerary text that shows a different use of $h m$. In $C T$ I, p. I48b [37] the living speaker addresses his dead father with the honorific title $h m . .^{70}$

To summarize, it is highly unlikely that $h m=k$ in BD chapter I 66 refers to a private individual owing the papyrus inscribed with this text. In view of the opening line discussed in section 2 it is more likely to designate Ramses II.

\section{Translation}

The translation follows Papyrus Berlin $303 \mathrm{I}{ }^{7 \mathrm{r}}$

$$
\begin{aligned}
& \text { V,2 } \quad \text { t3 } m \underline{d} \text { 3.t j-gmj<.t>rhh } n \text { n nsw.t } \\
& \text { Wsr-m3.t-Re Stp<.n R`> `.w.s. } m \text { hr.t } \\
& n \underline{t r} \\
& \mathrm{~V}, 3^{72} \quad j w-r-b-g j k m-m-r j{ }^{\complement}-m g j k-r-\underline{h}{ }^{\complement} m j \\
& k-m-r
\end{aligned}
$$

The scroll found on the neck of king Ramses II, Userma'atre Setep<enre> 1.p.h. in the necropolis.

$\mathrm{O} w-r-b-g, \mathrm{O} k m-m-r, \mathrm{O}^{\mathrm{e}}-m g, \mathrm{O} k-r-$ $\underline{h}^{\top} m, \mathrm{O} k-m-r$,

die Könige der ersten vier Dynastien (München, I969), 25ff; BD chapter I34 II: A text discovered in the palace in the time of the $h m$ of Semty (I. Munro, Der Totenbuch-Papyrus des Hohenpriesters Pa-nedjem II. [pLondon BM I0793/pCampbell] [HAT 3; Wiesbaden, I996], pl. 31, Kol. 30, I8); BD chapter I30: A text discovered in the palace in the time of the hm of Semty (C. H. S. Davis, The Egyptian Book of the Dead: The Most Ancient and the Most Important of the Extant Religious Texts of Ancient Egypt Edited, with Introduction, a Complete Translation and Various Chapters on Its History, Symbolism, etc. [New York, I 894], pl. LIII, Kol. 28).

69 Osiris: $C T$ I, I 02/ıо3a [32]; BD chapter Iо I (P. London BM EA I0477/P. Nu, G. Lapp, The Papyrus of $N u$ (BMEA I0477) [Catalogue of Books of the Dead in the British Museum I; London, I997], pl. 79, col. I2); BD chapter I80 (P. Paris Louvre 3073, Kol. 7, for the transliteration see B. Backes, in: TLA [Februar 20I3]); BD chapter I 83 (P. London BM 990 I/P. Hunefer, R. Lepsius, Das ägyptische Totenbuch I [Leipzig, I842], pl. CCIX, Kol. 33); sun god: BD chapter 5 (C. H. S. Charles, The Egyptian Book of the Dead (P. Turin Museo Egizio I79I) [New York, I90I], pl. IV, Kol. 5 and I I and pl. VI, Kol. 44); BD chapter 92 (Davis, The Egyptian Book of the Dead, pl. XXXIII, Kol. 3); BD chapter I40 (Davis, The Egyptian Book of the Dead, pl. LVII, Kol. 3); Thot: BD chapter io I (P. London BM EA ı $477 /$ P. Nu, Lapp, Papyrus of Nu I, pl. 79, Kol. I2); P. Kairo CG 5 I I89/P. Juja (I. Munro, Die Totenbuch-Handschriften der I8. Dynastie im Museum Cairo [ÄA 54; Wiesbaden, I 994 ], pl. 57, col. 421); BD chapter I 72 (P. London BM 9900/P. Nebseni, Kol. 26, for the transliteration see B. Backes, in: $T L A$ [Februar 2013]); Shu: BD chapter 24 (Davis, The Egyptian Book of the Dead, pl. XV, Kol. 6); Seth: CT IV 320e-32 I b [335]/TI C; goddess of the west: referred to as $h m . t: C T$ I, I07b and $C T$, I I 4a [32]; uncertain: there are two texts where the setting of the text is incomprehensible and therefore it is uncertain whether a 'servant' or a 'majesty' is meant. In $C T \mathrm{~V}, 4 \mathrm{ob}$ [377]/M23 C, hm is connected with Nehebkau; in CT VI $252 \mathrm{f}$ [630] (Sq6C) $h \mathrm{~m}$ is connected with $\underline{t} w$, meaning 'air' or 'breath'.

$7^{\circ} \quad$ H. Willems, 'The Social and Ritual Context of a Mortuary Liturgy of the Middle Kingdom (CT Spells 30-4I)', in H. Willems (ed.), Social Aspects of Funerary Culture: Proceedings of the International Symposium Held at Leiden University, 6-7 Fune, I996 (OLA 103; Leuven, 2001), 308, n. 220; for this exceptional use in private texts, cf. n. 64 .

${ }_{7 \mathrm{I}}$ For the sigla of the parallels, see J. Černý, 'Le caractère des oushebtis d'après les idées du Nouvel Empire', BIFAO 4I (I 942), I 25-9; see also the synopsis of Allam, Papyrus Berlin 303I. The version of P. Berlin $303 \mathrm{I}$ belongs to a female owner. There are five parallels $\left(\mathrm{L}_{3}, \mathrm{~W}, \mathrm{~K}_{2}, \mathrm{~K}_{\mathrm{I}}, \mathrm{K}_{5}\right.$ ) belonging as well to a female owner and nine other parallels $\left(\mathrm{K}_{3}, \mathrm{~K}_{4}, \mathrm{P}_{10}, \mathrm{P}_{\mathbf{2}}, \mathrm{K} 6, \mathrm{~K}_{7}, \mathrm{~L}_{2}, \mathrm{~L}_{4}, \mathrm{~L}_{5}\right)$ belonging to a male owner.

${ }_{72}$ For writing the 'secret' names, BD chapter i 66 (like the other 'chapitres supplémentaires') uses syllabic

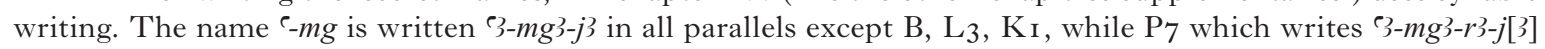
(Allam, Papyrus Berlin 303I, pl. 2). Wüthrich (Eléments de théologie thébaine, 105-6, n. 28-33) associates the names to Osiris, suggesting translations of the names. She refers in this context also to other interpretations: T. G. Allen, The Book of the Dead or Going Forth by Day (SAOC 37; Chicago, I 974), 216, n. 336 argues that these names 


$\mathrm{V}, 4 \quad \begin{aligned} & n 3 y w-n-r-m t \\ & \text { hrp } n=w \\ & \end{aligned} \quad$ wtt

$\mathrm{V}, 4-5 \quad j m j \underline{h r}=\underline{t n} n j 3 k b \cdot y^{75}<r->\underline{d} r^{76}$
$\mathrm{V}, 5 \quad s w$ mwt.tj $m g 3 . w s m 3 s n=f^{77} j r s(t) s 3$ $n k t^{7^{8}}$

(even you,) the $w$-n-r-mt, (even you,) who cast for $\mathrm{Re},{ }^{73}$ the shining sun, in order to control for themselves whatever exists, so they say. ${ }^{74}$

Pay attention to the mourned one, all $<$ of you $>$.

He is dead and in want, even the one whom his brother killed. The son did it as a Ketcha-crocodile.

have a Semitic background, while others argue for a Meroitic background, see K. Zibelius-Chen, 'Die nichtägyptischsprachigen Lexeme und Syntagmen in den chapitres supplémentaires und Sprüchen ohne Parallelen des Totenbuchs', LingAeg I3 (2005), 209; A. von Lieven, 'Nun sprach aber Osiris zu Re... Götterdialoge in den großen Korpora der ägyptischen Funerärliteratur', in A. El Hawary (ed.), Wenn Götter und Propheten reden Erzählen für die Ewigkeit (Narratio aliena? 3; Berlin, 2012), 93.

73 The $n R^{\complement}$ in P. Berlin 303 $\mathrm{I}$, as translated here, is a reinterpretation of $r^{-}$- , which is written in all other versions (Allam, Papyrus Berlin 303I, 87). These texts accordingly have $n 3 w d h . w r-{ }^{-} j t n$, 'those who cast at the side of the sun disc'.

74 Wüthrich, Eléments de théologie thébaine, 98 , reads the name as wn-r3-mwt, 'ceux qui ouvrent la bouche du mort'. We see no compelling reason to accept that the common expression $w n r$ was written in such an uncommon way. Moreover, in the funerary literature, the expression $m w t$ as referring to the deceased would probably have been avoided at all costs, the whole purpose of the funerary rituals being to avoid death. One would rather expect expressions like $b 3$ or $3 h$. The second part of the passage has been translated rather freely; a literal translation would be something like '(even you,) the $w-n-r-m t$, who cast, so they say, for Re the shining sun, in order to control for themselves whatever exists'. In this sentence the whole phrase after $w-n-r-m t$ is to be seen as an apposition.

75 Černý, Barguet, and Wüthrich assume that $j 3 k b . y$ is here used in the active voice as 'celui qui se lamente' ou 'Gémissant' (Černý, BIFAO 4I [1 942], i I 8; P. Barguet, Le Livre des Morts des Anciens Égyptiens [Paris, I 967], 239, n. 239; Wüthrich, Éléments de théologie thébaine, 98; also LGG I, I I4). According to Barguet, this would refer to Osiris, who had been killed by Seth. While this conclusion is ultimately correct, Osiris is never portrayed as lamenting himself. It would be more normal to assume that he would be lamented by others (like Isis or Horus). Since references to deities like these are lacking, it seems more likely that $j 3 k b . y$ is a passsive participle, describing Osiris as 'the lamented/mourned one'. The ending . $y$ fits a passive participle well (see already Allam, Papyrus Berlin 303I, I35, n. f., who translates 'der zu Beklagende').

76 For $<r->\underline{d} r$ (without suffix pronoun) see $W b$. V, 59I, I-8. The same use occurs in P. Berlin 303 I, V,7.

77 P. Berlin 303 I reads $s m 3 h m=f$, the $h m$-sign being likely a confusion for $s n$, which has a closely similar form in hieratic. In a recent translation, A. Wüthrich correctly understood it as referring to Osiris (Wüthrich, Éléments de théologie thébaine, 98 ), with reference to whom it is said '(Osiris) ... son frère l'a tué, son fils l'a transformé en crocodile' $\left.\left(s m_{3}<s w>s n=f i r i s w s\right\}=f n k t\right)$. Here, two comments should be made. First, Wüthrich's rendering has to insert the pronoun $s w$, which is nowhere written. It seems better therefore to assume that $s m 3 s n=f$ is a relative form. Secondly, many versions replace $k \underline{t}$, 'crocodile', with the name of the god Mega. Since this was a crocodile god, $k \underline{t}$ may simply be a variant designation of the same deity, and it is unlikely that Osiris is understood as being transformed into the son of Seth. Based on these considerations, we suggest to read: '(Osiris), whom his brother killed. (In fact), his (i.e. Seth's) son Mega did it (i.e. the killing)'. For a possible etymology of $k \underline{t}$, see Quack, $W d O$ $4 \mathrm{I}, 258$.

${ }_{78}$ The variants show there was some confusion over the identity (cf. Allam, Papyrus Berlin 303I, pl. 6):

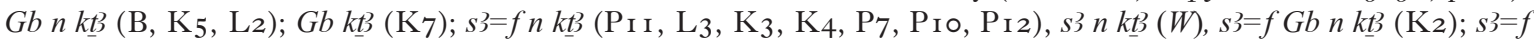
$k \underline{t}\left(\mathrm{~L}_{5}\right) ; m g 3 \mathrm{k} \underline{3}(\mathrm{KI}) ; m g 3 m k \underline{t}$ ( $\left.\mathrm{K} 6\right)$. We assume that ' $\mathrm{Geb}$ ' is a miswriting for the sign for $s 3$ (both words being written with a goose sign). It is noteworthy that $M g$ ? mentioned in $\mathrm{KI}$ and $\mathrm{K} 6$ is known from other sources as the son of Seth and Nephthys (see A. von Lieven, 'Seth ist im Recht, Osiris ist im Unrecht! Sethkultorte und ihre Version des Osiris-Mythos', ZÄS I33 [2006], I45-6; von Lieven, Grundriß des Laufes der Sterne, I97; Quack, $\left.W_{d O} \mathrm{I}_{2}, 258\right) . M g$ ? is moreover usually written with the determinative of a crocodile, suggesting that $k \underline{t}$ refers to him. The passage may allude to Mega, the son of Seth. Our reading implies that Mega/Ketja took sides with Seth and killed Osiris for him; on Mega attacking Osiris, see also M. Wagner, 'Konzeption von Gespräch und Rede auf dem Sarkophag der Gottesgemahlin Anchnesneferibre', in A. El Hawary (ed.), Wenn Götter und Propheten reden - Erzählen für die Ewigkeit [Narratio aliena? 3; Berlin, 201 2], 107-10). This article also offers a justification for the translation of $s m 3 s n=f$. There is possibly a pun between the name $m g$ ? and the formulation $m g$ ?. $w$ in this text. 


$$
\begin{array}{ll}
\mathrm{V}, 5-6 \quad & n n w^{\odot} / r n h p=f h r j w=w^{79} \text { rjnj<.t> } \\
& b 3=f r t 3 w s h . t m 3^{\complement} . t j m-b 3 h \text { M- } m-r-m- \\
& k-h-b
\end{array}
$$$$
\mathrm{V}, 7 \quad n b=n^{8 \circ} r-d r w s ̌ b s w^{8 \mathrm{I}} r h f . t j=f
$$$$
\text { V,7 j j } \quad \text { 3 m3j km-ḥrdšr jr.tj hrst }{ }^{82} j m j
$$$$
\text { VI, I } \quad s p . t j=f p 3 s m 3 r n=f n 3 h f . t j w n j t(=f)
$$$$
\text { jw bw } \underline{t} j . t<w>^{83} \text { dm.t } r=w
$$

$$
\begin{array}{rl}
\mathrm{VI}, \mathrm{I}-2 & M-m-r-m-k-h-b r n=k / h h t j=j\{=f\}^{84} \\
& s w h r p s \underline{d} n h m=k
\end{array}
$$

VI,2-3 jmj $h r=k n=f^{86} r r d j=k n=f 3 h . t m$ sh.t / j3rw htp.w ndm<.w> m sh.t $j w-\underline{t} 3 m w . t$

$$
\begin{aligned}
& \text { VI,3-4 mj } r=k n W \operatorname{sjr} N^{87} \\
& \mathrm{VI}, 4 \quad \text { jmj } n=s \underline{t w n} n \text { jr.t b3.w } w^{88} \text { htp.w mj } \\
& h m=k<r>^{89} m r j=k
\end{aligned}
$$

There is (now) no one to take care of him. But his Ba will be brought to the Hall of the Two Ma'ats in front of $M-m-r-m-k-h-b$.

O lord of us all, protect him from his enemy.

O black-faced Lion, with red eyes, and whose lips are carnelian-red, whose name is 'the one who kills the enemies of his father, while not (even) a sword is taken up against them.'

$M-m-r-m-k-h-b$ is your name. I will engrave it ${ }^{85}$ on the back of your majesty.

Pay attention to him (= the deceased), so that you may give him a plot of land in the Field of Rushes and sweet offerings in the Field of the Island of Djeme.

\section{Come to Osiris N!}

Give her a donation to exert $b 3 w$ power and peace like your majesty according as you like.

79 The suffix $=w$ could refer either to the 3 rd person plural or to the passive. The translation depends on the interpretation of the setting of the involved persons. One of the parallels, K6 (Allam, Papyrus Berlin 303 , pl. 7 ), writes $j w=s t$ instead of $j w=w$, showing that in this variant the 3 rd person plural is meant. Considering the context, a passive, however, seems more likely.

80 Some versions do not read $n b=n\langle r\rangle \underline{d} r$ but $n b r \underline{d} r$, 'Oh Lord of All' (P I I, L 3 , W, Pio, P I2, K6). An exact parallel to the construction found here, with $<r->\underline{d} r$ specifying the suffix $=n$, compare for instance P. Phillips, I4 (J. Černý, Late Ramesside Letters [Bibliotheca Aegyptiaca IX; Bruxelles, I 939], 29, I 5).

${ }_{8}$ I The question here is to whom the pronoun $s w$ refers: the third person singular pronouns in the preceding sentences referred to j3kb.y and this could also be the case here. However all other parallels of the present passage specify the lord of us all by the relative clause 'who is in front of him' ( $n t j j w=f m-b 3 h=f)$. This must allude to the ba being in front of $M-m-r-m-k-h-b$ as stated in the preceding sentence $(\mathrm{V}, 6)$.

82 Hrst: the grammatical construction shows this must be the verb hrst, not the noun $h r s . t$ (Wb. III, I 5I, I2). All versions except $\mathrm{K}_{4}$ and $\mathrm{L}_{5}$ read jm.y sp.ty=f, literally 'that which is between his lips'. This may refer to the opened mouth of the lion.

$8_{3} \quad$ Bw $\underline{t}$ j.t. $\left\langle w>\right.$ : see n. $45^{-53}$.

$84 \quad \mathrm{P}$. Berlin $303 \mathrm{I}$ is the only text which has the suffix $=f$ (Allam, Papyrus Berlin 303I, pl. I I ). The majority of parallels have the suffix $=j$. Therefore it is obvious that $\mathrm{P}$. Berlin $303 \mathrm{I}$ made a mistake. In $\mathrm{K}_{5}, \mathrm{~L}_{2}$, and $\mathrm{L}_{4}$ is written the suffix $=k$, which does not make sense. P I 2 and $\mathrm{K}_{\mathrm{I}}$ insert 'Osirs N' after hm=k (Allam, Papyrus Berlin $303 I$, pl. I I) while in K6 the name 'Osiris N' is noted above the line. This could be understood as a later addition to the original text supposedly found on the neck of Ramses. In $\mathrm{K}_{5}, \mathrm{~L}_{2}, \mathrm{~L}_{4}, \mathrm{~L}_{5} h m=k j 3 k b . y$ is written instead of $h m=k$.

85 For 'engraving a name' on a mummy, see the interpretation below.

86 In P. Berlin $303 \mathrm{I}$ is written the suffix $=f$, but all other versions written for female owners feature the suffix $=\mathrm{s}_{3}, \mathrm{~K}_{2}, \mathrm{~K}_{\mathrm{I}}, \mathrm{K}_{5}$ [Allam, Papyrus Berlin 3o3I, pl. I 2]). Therefore it is likely that the suffix refers to the owner and that the Berlin papyrus contains an error.

87 This sentence occurs only in P. Berlin $303 \mathrm{I}$. It is notable that this sentence marks the change from 'him' to 'her' in connection with the request for fields, $b 3 w$-power, etc. 


$$
\begin{array}{ll}
\text { VI,4-5 } & j m j \underline{h} n d=s / h r \text { s.t } n b . t n m r j=s j w=s n \\
& h p r n b n j b=s \\
\text { VI,5-6 } & j M-m-r-m-k-h-b n b=n^{91} \\
& p t r n 3 / w s ̌ b . t j<. w>9^{2} n 3 h m . w h m . w t \\
& n s j s t^{93} h m=k<j 3 k b . y>\{W \text { sjo } N\}^{94}
\end{array}
$$

$\mathrm{VI}, 7 \quad h m . w=s n 3 . w m-\underline{d} r w n=s h r-t p t 3 n t s$ j-jnj sn m snn.ty $=s^{95}$
Enable her to walk wherever she likes while she is in any form she likes. $^{90}$

O $M-m-r-m-k-h-b$, our lord!

See the shabtis, the male and female servants. They belong to your majesty, the mourned one $\{$ Osiris N\}.

They were her servants when she was on earth. It is she who bought them for their price.

88 The word written here as $d w n$ must be $t w n$, 'allowance', 'allotment', 'gift' ( $W b$. V, 36o, I). Černý translates 'Donne lui la force de faire que les esprits soient propice ...' (BIFAO 4I, I I 9). This rendering (which was followed with insignificant differences by Barguet, Livre des Morts, 239 and Allam, Papyrus Berlin 303I, I35) implies that the verb $j r j$ has causative force. However, for this, Egyptian uses the verb $r d j$. It is far more likely that we are here facing the expression jrj.t b3.w, which occurs, e.g., in O. DeM 25I (J. Černý, Catalogue des ostraca hiératiques non-littéraires de Deir el-Médineh IV [Documents de fouilles 6; Le Caire, 1939], pl. 3) or O. Leipzig I I (HO I, I6.I and I44.I). J. F. Borghouts has shown that $b$ 3.w is a 'manifestation' of a god. jrj.t b3.w is a technical term that refers to a god making his own manifestation or that of another felt in the world ('Divine Intervention in Egypt and Its Manifestation [b3w]', in R. J. Demarée and J. J. Janssen [eds], Gleanings from Deir el-Medîna [EU I; Leiden, I 982], I-70; the ostraca are discussed on p. I 5-22). The sense of our passage would seem to be that the owner of the papyrus, just as 'your Majesty', obtains these powers.

${ }_{9} \quad$ The $r$ is present in most parallels.

$9 \circ \quad$ Literally: 'of her heart'.

9I All parallels proceed after 'O $M-m-r-m-k-h-b$, our lord' with $j \underline{t} j \underline{t} . w=n r \underline{d r} . w$, 'who takes the breath of us all' (Allam, Papyrus Berlin 303I, pl. I 5). Wüthrich, Éléments de théologie thébaine, Iо8, n. 40-I, and H. D. Schneider, Shabtis: An Introduction to the History of Ancient Egyptian Funerary Statuettes I (Leiden, 1977), 327, n. I6, link the name to the epithet $r d j \underline{j} \underline{w} w$ of Amun. They understand the titles as stressing the ability of Amun to give or take breath according to his wish. However, it sounds odd that in a wish for the well-being of the deceased, Amun's capability of taking away breath would be underscored. A possibly better explanation is that the sentence expresses the ability of $M-m-r-m-k-h-b$ to take away the breath in his role as the judge of the netherworld: 'Who can take away the breath of us all' or similar (cf. Gardiner, Egyptian Grammar, § 37I). According to A. von Lieven, this address to the god is followed by a reaction by the god ('Wechselrede'); see 'Nun sprach aber Osiris zu Re ... (Götterdialoge in den großen Korpora der ägyptischen Funerärliteratur)', in A. El Hawary (ed.), Wenn Götter und Propheten reden - Erzählen für die Ewigkeit (Narratio aliena? 3; Berlin, 201 2), 93. We do not understand how the text can be interpreted in this way.

92 As Černý, BIFAO 4I, I $5_{5-1} 8$, has shown, the theme of shabtis being bought and paid for by the deceased appears besides BD chapter 166 in the shabti decree of the god Amun to the deceased Nesikhons, which occurs on two hieratic boards, the McCullum tablet (British Museum) and the Rogers tablet (Louvre). In this decree, Amun declares that the shabtis of Nesikhons will work for her. The first and second parts focus on the service they render to the deceased throughout the year. The third part gives the important information that the owner of the shabtis has bought them for a price that equals the value of the work they perform. On p. I I6-i 8 , Černý also analyses the meaning of $h \mathrm{~m}$ in the context of the shabtis. In BD chapter I 66 the shabtis are called $h \mathrm{hm.w} h \mathrm{hm.wt}$, 'male and female servants'. He compares the payment for the work of the shabtis with the payment for the work of servants. In this meaning the shabtis are not substitutes for the deceased but rather his servants, who work for him in the netherworld. Schneider, Shabtis, 328-30 in this connection also refers to another document from the Twenty-First or Twenty-Second Dynasty previously discussed by I. E. S. Edwards, 'Bill for a Set of Ushabtis', $\mathcal{F E A} 57$ (I971), I20-4, pl. 32. The aim of this document was to state the ownership of the shabtis belonging to the priest Espernub, the son of Ihafy.

93 Written $n s y s w$, but undoubtedly the plural is meant.

$94 \mathrm{P}$. Berlin $303 \mathrm{I}$ writes $W \operatorname{sjr} \mathrm{N}$ after $h m=k$. At first sight this might suggest that $h m=k$ refers to the nonroyal papyrus owner. The reading in $\mathrm{K} 6$ (nsj st $h m=k j 3 k b . y \mathrm{~N})$ and in $\mathrm{K}_{\mathrm{I}}(n s j s t h m=k j 3 k b . y n s j$ st $h m=k$ Wsjr $\mathrm{N}$ ) could be interpreted in the same way. We have, however, argued that $h m=k$ refers only to gods or kings. This is confirmed in this passage by the fact that all other parallels read $j 3 k b . y$ instead of $W s j r \mathrm{~N}$. In addition, it is not absolutely certain that versions B and K6 mention the deceased in apposition to $h m=k$. Another possibility is that two persons are mentioned in coordination $(h m=k$ and $W s j r \mathrm{~N})$. This would agree well with the argument of the whole passage, that the shabtis belong to both persons.

95 For the orthography and translation of snn.ty see Černý, BIFAO 4I, I 25-9. 
VI,7- $\quad j m j \underline{h} r p=s<s . t>h r-t p 3 . t$

VII, I

$\begin{array}{ll} & j m j j r j=w k 3 . t r-\underline{d} b 3=s j r 3 . t \text { n.t } \\ & s h \underline{3}=s^{96} \\ \text { VII, I-2 } & n t k p 3 y=s / m t r n f r r^{97} m-b 3 h=k M-m-r- \\ & m-k-h-b\end{array}$

VII, 2-3 $m \underline{t} n=k n b j r=k s w n^{98} h m=k m-\underline{d} r$ $\check{S}^{\prime}=s m d 3 . t=s m-b 3 h=k$
Let her lead $<$ them $>$ at the (right) moment.

Let them work in her stead at the time she is thought of.

Her good testimony in your presence belongs to you, $M-m-r-m-$ $k-h-b$.

All your allotments, may you, even your majesty, provide them whenever she recites her scroll in your presence.

\section{Interpretation}

The translation suggests BD chapter $\mathrm{I} 66$ should be divided into two parts differing in focus. Part I (V,2-VI,2) repeatedly addresses 'your Majesty' and nowhere mentions the name of the private papyrus owner, who is, however, the focus in part II (VI,2-VII,3). 'Your Majesty' is only rarely mentioned here and seems to be a person different from the papyrus owner. This part also raises topics of direct relevance to a private deceased, such as the provision with a plot of land in the netherworld, the exertion of $b 3 w$-power and the empowerment of his shabtis. The break between the two parts is quite obvious. Since part I, with 'Your Majesty' playing the crucial role, follows immediately after the introduction to the text $[\mathrm{V}, 2]$, which claims that what follows is a copy of a text found at the neck of the mummy of Ramses II, we suggest that this introduction refers only to part I, whereas part II was added later for the benefit of the private papyrus owner. In what follows we will look at each part in detail.

Part I [V,2-VI,2]:

Part I features a whole series of designations for divinities that are not found elsewhere. As a result, the mythological background of the text can only be deciphered by close reading. We have approached it according to the method of sequencing recently proposed by Willems (see n.7), which aims at establishing the number of 'persons' featuring in a text, the places where they operate, and the sequence in which they do so.

${ }_{96}$ I.e. the moment she is asked to perform certain tasks in the netherworld, comparable to the situation in BD chapter 6 .

97 This is usually read as a nominal clause, 'you are her witness'. Since the passage is part of an address to $M-m-r-m-k-h-b$, who earlier in the text seemed to appear in the role of a judge in the Hall of the Two Ma'ats, this is unlikely, since this would conflate the roles of judge and witness. We read a possessive clause, the implication being that $M-m-r-m-k-h-b$ 'has' a positive testimony at his disposal. The parallels $\mathrm{P}_{12}, \mathrm{~K}_{6}, \mathrm{~K}_{7}, \mathrm{~K}_{5}, \mathrm{~L}_{2}, \mathrm{~L}_{4}$ and $\mathrm{L}_{5}$ have the suffix $=w$ instead of the third person singular suffix. It seems that in these parallels the suffix refers to the shabtis and not to Osiris $\mathrm{N}$.

${ }_{98}$ Reading the $n$ as a dative brings us to an illogical sentence in which $M-m-r-m-k-h-b$ provides his allotments to himself (addressed as 'your Majesty'). Therefore the $n$ is to be read as the preposition $m$, as often happens in Late Egyptian, and is in fact encountered earlier in the same text $(\mathrm{VI}, 5)$. In $\mathrm{L}_{2}$ and $\mathrm{L}_{5}$ no preposition is written, suggesting $h m=k$ is an apposition. This can in Late Egyptian also be effectuated by the $m$ (here $n$ ) of identification (e.g. O. DeM 580, vsi-2: S. Sauneron, Catalogue des ostraca hiératiques non-littéraires der Deir el-Médineh [Nos 550-623] [Documents de fouilles I 3 ; Le Caire, I 959], pl. I 5). In $\mathrm{K} 6, \mathrm{~K}_{7}, \mathrm{~K}_{5}, \mathrm{~L}_{2}, \mathrm{~L}_{4}, \mathrm{~L}_{5} \mathrm{have}_{h m=k} 3 k b . y$ as in VI,6. The version of PI2 obviously misunderstood the $n$ as a dative, considering it necessary to identify $h m=k$ with Wsjr N. 
An important part of the method is that it should be recognized that single individuals or places may be referred to by different designations within a single text. In part I, the following persons are referred to (since only one place name is mentioned, this will not be dealt with in a separate section):

(I) The dead king Ramses II, who is mentioned only in the title of BD chapter I 66 and is never mentioned again $[\mathrm{V}, 2]$. As pointed out in section 4 , the term $h m=k$ almost exclusively refers to kings or deities in funerary texts. This strongly militates against earlier interpretations of $\mathrm{BD}$ chapter $\mathrm{I} 66$, based on the assumption that $h m=k$ refers to the private person owning the papyrus. We argue for an interpretation of $h m=k$ as the king. As BD chapter $\mathrm{I} 66$ mentions king Ramses II, it must be he who is spoken of as $h m=k$.

(2) A speaker addresses a group of five gods in $\mathrm{V}, 3-6$. Somewhat later in the text, in a passage formulated in the first person singular, the speaker states he will engrave the name of $M-m-r-m-k-h-b$ on the back of $h m=k$. If $h m=k$ is Ramses II (I), as argued above, this remark can only refer to a ritual act performed on the king's mummy, suggesting that the speaker represents a ritualist interacting with the individual characters.

(3) $j 3 k b . y$ : The meaning of his name, 'the Mourned One', implies he is dead. Various elements in the text suggest that j3kb.y is Osiris: he is said to have been killed by his brother and by Mega $[\mathrm{V}, 5]$, the son of Seth (see. n. 78); the statements to the effect that he is 'dead and in want' and that his body is unattended $\left[\mathrm{V}, 5^{-6}\right]$ probably refer to the dead body of Osiris awaiting its resurrection. The formulation of [V,6] implies that $j 3 k b . y$ has a ba (this will be explained under (6).

(4) A group of five gods: The speaker (2) addresses them with their personal names $w-r-b-g, k m-m-r, c^{-}-m-d, k-r-h m$ and $k-m-d-r-j[\mathrm{~V}, 3]$. They are also designated as a group called the $n 3 y$ w-n-r-mt $[\mathrm{V}, 4]$. These gods are asked in $\mathrm{V}, 4-5$ to 'pay attention to the Mourned One' (3), whom we have seen to be the corpse of Osiris. This means that the five gods must be considered as the protectors of the netherworldly booth sheltering the corpse of Osiris. The text indicates that these deities are also called 'those who cast for Re in order to control for themselves whatever exists' [V,4]. This explicitly subordinates the group to Re.

(5) $M-m-r-m-k-h-b$ : According to [V,6-VI.I] a person is ushered into his presence in Wsh.t $m 3$ '.tj, 'the Hall of the Double Truth.' This is the hall of judgment where the events evoked in $\mathrm{BD}$ chapter ${ }^{2} 5$ take place. ${ }^{99}$ According to that text, the hall is presided over by Osiris. In BD chapter I 66, the god in charge is called $M-m-r-m-k-h-b$, who accordingly seems to be playing the role of an Osiris-like deity. His relationship to j3kb.y (3), another Osirian figure, will be addressed later.

(6) The $b 3$ : In $\mathrm{V}, 5^{-6}$ the ba is said to be brought into the Hall of the Double Truth in front of $M-m-r-m-k-h-b$. The fact that he is ushered into this Osirian hall places him in the structural position of a deceased being brought into the hall of divine judgment. Different from BD chapter I 25, BD chapter i 66 alludes to this situation, but does not go into the details of the judgment of the dead. Instead it switches to a new topic. It is very important that $\mathrm{V}, 5^{-6}$ does not simply refer to a ba, but that it speaks of 'his ba'. The pronoun is likely to refer to someone mentioned earlier, and in the present context this can only be $j 3 k b \cdot y(\mathrm{~V}, 4-5)$. Thus, (6) is the ba of (3). 
(7) The 'Lord of us all': This person $(\mathrm{V}, 7)$ is addressed by a group ('us'). Since the only group mentioned before is (4), it seems certain that it is these five gods who address him, urging him to protect an unspecified 'him' against 'his' enemy. In most of the parallels of BD chapter i 66, 'The lord of us all' is further identified as 'the one who is in front of him'. ${ }^{100}$ This clearly alludes to V,6, where the ba (6) is brought 'in front of $M-m-r-m-k-h-b$ ' (5). Therefore, the 'The lord of us all' (7) and the ba (6) are likely to be identical.

(8) The 'Black-Faced Lion' (etc.): Immediately after the invocation to (7) follows a second invocation to a being described as a 'Lion.' According to his epithets, he protects his father against his enemies [V,7-VI.I]. This recalls the request to (7) and therefore we assume that both invocations are directed to the same person. The implication is: (6) $=(\mathbf{7})=(8) \cdot{ }^{101}$

The above analysis reveals a scenario which at first seems to be very complex because of the many different personal names, but which in fact has a rather simple underlying structure. Thus, the ba (6), the 'Lord of us all' (7) and the Lion (8) are probably a single person. Beside him, another protagonist is referred to with two names: $j 3 k b . y(3)$ and $M-m-r-m-k-h-b(\mathbf{5})$ are both designations of an Osiris-like entity, which is 'bifurcated' 102 into two different aspects: on the one hand, he is described as a weak and dead person in need of protection (3), on the other he presides over the Hall of the Double Truth (5), making it likely he is a judge and thus endowed with great powers. This contradiction becomes understandable once the character of Osiris is taken into consideration. In him, these passive and active roles merge: he is on the one hand the helpless victim of Seth, yet also the judge and lord of the netherworld. $M-m-r-m-k-h-b$ and $j 3 k b . y$ therefore need to be viewed as the active (empowered) and passive (powerless) aspects of one Osiris-like deity. The connection between these two is mediated by the ba, who is said to protect 'him' against his enemy. While the 'him' refers back to the previously mentioned $M-m-r-m-k-h-b$ (see n.8I), the need for protection places him on a par with the unattended $j 3 k b \cdot y$.

The text also implies movement, as it states that the ba $\mathbf{( 6 )}=\mathbf{( 7 )}=\mathbf{( 8 )}$ moves to Osiris (3) $=\mathbf{( 5 )}$. This corresponds to the well-known merger of two gods bringing both of them back to life. Religious texts describe this idea in different ways, as for example the merger of the ba with its mummy, ${ }^{103}$ the son (several gods, i.e. Horus or Shu) with his father (several gods, i.e. Osiris or Atum), ${ }^{104}$ and notably as the enigmatic and regenerative merger of Osiris and Re in the middle of the night, which is often evoked

ıо The address $n b=n r-d r$ is followed by $n t j j w=f m-b 3 h=f\left(\mathrm{P}_{\mathrm{I}}, \mathrm{L}_{3}, \mathrm{~W}, \mathrm{~K}_{2}, \mathrm{P}_{\mathrm{I}}\right.$, $\left.\mathrm{P}_{\mathrm{I} 2}, \mathrm{~K}_{\mathrm{I}}, \mathrm{K}_{4}, \mathrm{~L}_{2}\right)$ or $n t j$ $m-b 3 h=f\left(\mathrm{~L}_{4}, \mathrm{~L}_{5}\right)$, see Allam, Papyrus Berlin 303I, pl. 8. However, some versions show a different setting: $\mathrm{K}_{3}$ and K6 write $n t j j w=w m-b 3 h=f$, 'Lord of (us) all [b3] in front of whom they are'. These two versions show an interaction between the previously invoked group of gods and the $\mathrm{Ba}$ as Lord of all. Given the solar character of both the $\mathrm{Ba}$ and the group (see $\mathrm{V}, 4$ ) the connection is understandable. It does not contradict the other versions.

Iо $\mathrm{H}$ Here, our conclusion differs from earlier interpretations as in Schneider, Shabtis, 326.

102 A term coined by Terence Turner in his structural analysis of the ancient Greek Oedipus Myth ('Oedipus: Time and Structure in Narrative Form', in R. Spencer [ed.], Forms of Symbolic Action [Seattle, I 969], 26-68).

103 J. Assmann, Tod und Fenseits im Alten Ägypten (München, 2001), I 28-3 I and 247-54.

104 H. Willems, 'The Embalmer Embalmed: Remarks on the Meaning of the Decoration of Some Middle Kingdom Coffins', in J. van Dijk (ed.), Essays on Ancient Egypt in Honour of Herman te Velde (EM r; Groningen, I 997), 359-64. 
in the royal tombs of the New Kingdom in the Valley of the Kings. ${ }^{105}$ This merger is the crucial point in BD chapter $\mathrm{I} 66$ part I, as we can see in VI, I. Here the speaker says to the ba (Lord of us all/Lion; $(\mathbf{6})=(\mathbf{7})=(\mathbf{8})$ ): ' $M-m-r-m-k-h-b$ is your name.' At this point the merger has been accomplished and the transformation is achieved. Thus, BD chapter I 66, part I, at first differentiates the ba/'the Lord of Us All'/the Lion (6) $=\mathbf{( 7 )}$ $=\mathbf{( 8 )}$ from $j 3 k b \cdot y / M-m-r-m-k-h-b \mathbf{( 3 )}=\mathbf{( 5 )}$, whereas at the end of part I the two appear transformed into a single being $M-m-r-m-k-h-b$.

The last sentence of Part I adds a further dimension to the situation. The anonymous speaker (2) here states that he engraves the name of the merged deity $M-m-r-m-k-h-b$ on the back of $h m=k$. Considering that $h m=k$ designates the king, who is in this text Ramses II, this seems to evoke a ritual layer: by writing the name on the mummy, Ramses II becomes one with $M-m-r-m-k-h-b$. There is archaeological evidence suggesting that such a practice of 'engraving' actually occurred. When G. Daressy unrolled the mummy of the Amun priestess Tadiamun, found in the Bāb al-Gasūs cachette, he noticed that 'Les inscriptions des bandelettes et linges de la momie $\mathrm{N}^{\circ}$ 29707, tracées au fer cha $\{\mathrm{n}\}(\mathrm{u}) \mathrm{d}$, sont à peu près illisibles; elles paraissent n'avoir donné que les noms des propriétaires des étoffes' ${ }^{106}$ Arguably, inscribing Ramses II's mummy with the name $M-m-r-m-k-h-b$ carried the implication that the dead king was identical with the ba $(\mathbf{( 6 )}=\mathbf{( 7 )}=\mathbf{( 8 )})$ who went through a dynamic process leading to his identification with Osiris $(\mathbf{( 3 )}=\mathbf{( 5 )})$. Thus, Ramses II is suggested to be the ba of Osiris who brings back to life the god's mummy $(j 3 k b . y)$, in the process transforming himself into the $M-m-r-m-k-h-b$-form of Osiris. In the following part II $h m=k$ and $M-m-r-m-k-h-b$ are one.

Part II [VI,2-VII,3]:

Part II takes as its point of departure the existence of the merged deity $M-m-r-m-k-h-b$ $/ h m=k$. If, in keeping with the outcome of part I, one keeps in mind that this is one person who could be addressed either as $M-m-r-m-k-h-b$ or as $h m=k$, the structure of part II regarding the characters involved becomes very simple. The only figure that appears beside $M-m-r-m-k-h-b / h m=k$ is the dead papyrus owner, who in the case of $\mathrm{P}$. Berlin 303 I was a woman. Part II in its entirety takes the form of an invocation to $M-m-$ $r-m-k-h-b / h m=k$, urging him to act for the deceased whenever she recites her scroll in front of him [VII,3]. Her request consists of two different wishes:

I. VI,2-VI,5: The speaker asks $h m=k$ to provide the deceased with an allowance, which enables her to exert $b 3 w$-power and $h t p . w$, to move freely, and to assume any form she likes.

2. VI, $-\mathrm{VII}, 2: M-m-r-m-k-h-b$ is asked to force the shabtis owned by the deceased to work for her (or him).

I05 See J. C. Darnell, The Enigmatic Netherworld Books of the Solar-Osirian Unity: Cryptopraphic Compositions in the Tombs of Tutankhamun, Ramesses VI and Ramesses IX (OBO I98; Fribourg, 2004); S. Wiebach-Koepke, Sonnenlauf und kosmische Regeneration: Zur Systematik der Lebensprozesse in den Unterweltsbüchern (ÄUAT 7I; Wiesbaden 2007); T. DuQuesne, 'Osiris with the Solar Disk', DE 60 (2004), 2I-5; A. Spalinger, 'Osiris, Re and Cheops', ZÄS I34 (2007), I73-84; A. Spalinger, The Great Dedicatory Inscription of Ramesses II: A SolarOsirian Tractate at Abydos (CHANE 33; Leiden, 2009), I00-2. The theme was present already in the Middle Kingdom, although then it was rather located at the end of the night (e.g. H. Willems, Chests of Life: A Study of the Typology and Conceptual Development of Middle Kingdom Standard Class Coffins [MVEOL 25; Leiden, I 988], I $52-4)$.
I06

G. Daressy, $A S A E_{3}$ (1 902), I 55 . 
These requests represent the core of part II. ${ }^{107}$ As we have seen in the translation and the commentary, the individual versions of the text vary in many details. However, all frame the shabti passage at the beginning and at the end by an address to $M-m-r$ $m-k-h-b$. One reason for this must be that $M-m-r-m-k-h-b$ (= Osiris) is the lord over the netherworld, who, by presiding over the Hall of the Double Truth, held the power to take decisive legal action. This is supported by the allusion to a 'good testimony' supporting the papyrus owner in VII, I-2. The legal aspect may also explain why VI,7 includes a remarkably profane statement to the effect that the owner of the text had duly paid for the shabtis.

At the culmination of part I, king Ramses II $/ h m=k$ became one with $M-m-r-m-k-h-b$, suggesting that it is at the same time he who takes these decisions. This impression is supported by the observation that VI,6 states that the shabtis belong to $h m=k .^{108}$ Therefore it is Ramses II $/ h m=k$ who activates the shabtis for the deceased.

In the final passage (VII,2-3), the mediator role of $h m=k$ is stressed again. Just as at the beginning of part II (VI,2-3), the address concerns the provisions provided by the god, summarized as 'allotments', which $M-m-r-m-k-h-b$ is asked to provide to the papyrus owner. In part I, the speaker was clearly an independent person (2) operating as a ritualist. The question is whether part II was also recited by a (living) ritualist. At the end of part II we can read: 'All your allotments, may you, as your majesty, provide them whenever she recites your scroll in your presence.' This implies that the deceased papyrus owner ('she') is speaking here to 'your Majesty', and that the king will take action to realize the positive effects (s)he expects. On the surface, this suggests that BD chapter 166 was meant to be a netherworldly recitation by the deceased with no ritual significance. However, it cannot be ruled out that the text was effectively recited by a priest when the papyrus bearing it was deposited on the mummy. This ritual statement then led to positive effects both for the king who had been the owner of the original papyrus (part I) and for the private person owning the reworked version, which included part II. From this moment onwards, the deceased would have been 'self-supporting', later repeating the ritual act by independently reading out the text in the netherworld. Although there is no way of proving the case, it seems inherently likely that the application of papyri containing BD chapter $\mathrm{I} 66$ was a ritual act in its own right, and we therefore tend to the view that the latter interpretation of the evidence has the greater likelihood.

\section{Summary and conclusions}

Current interpretations of BD chapter $\mathrm{I} 66$ usually disregard the introductory statement, which claims the text was found on the mummy of Ramses II. However, the presence of this statement cannot be denied, and ignoring it distorts the content of BD chapter i 66. We have therefore attempted to study the text, including its introduction, as a coherent whole, stressing that, for an interpretation of the religious content, it

\footnotetext{
${ }_{107}$ In version $\mathrm{K}_{7}$ the previous passage (VI,2-VI,5), asking the king for various provisions for the deceased, is skipped, moving directly to the shabtis passage and to addressing $M-m-r-m-k-h-b$.

108 In the version of P. Berlin $303 \mathrm{I}$, the designation $h m=k$ in this passage is complemented by the addition $j 3 k b . y$ Wsjr N. This exceptional variant renders the interpersonal relationships less easy to comprehend, and, as remarked in n. 94, is probably erroneous.
} 
makes little difference whether the introductory line factually describes a real event or whether it only pretends to do so.

We have shown that, in the form in which BD chapter I 66 has come down to us, it consists of a first part concerning only the king's resuscitation in the netherworld, probably in the context of a ritual performed on earth, and of a second part. This latter is clearly not of royal origin, as it tries to engage the dead but resuscitated king in helping a dead person in the hereafter. If there is any truth to the claim that the text was found on the mummy of Ramses II, this original version cannot have included part II.

Although it cannot be ruled out with certainty that the text of part I belonged to the original tomb equipment of Ramses II, the possibility that it was is rendered less likely by the fact that it is written in Late Egyptian, a kind of Egyptian not otherwise found in New Kingdom royal tomb inscriptions or in the Book of the Dead. Therefore, it might rather have been added to the mummy during its first reburial in the sixth year of Herihor (A) or during the second, in year I 5 of Pinodjem I, when it was transferred to the tomb of Seti I (B).

Here it might be added that, already in the Twenty-First Dynasty, BD chapter $\mathrm{I} 66$ is associated with at least one other of the chapitres supplémentaires: BD chapter I 62. This is the case on P. Berlin 303 I I, I-III,2. In terms of composition, the two texts moreover share the tendency to designate the main deities involved with incomprehensible, secret names. This suggests a common background. Since BD chapter 162 is thoroughly rooted in the theology of Amun, a connection with the Amun priests is not unlikely. In fact, the owner of P. Berlin 303 I derives from that social background. By contrast, Amun theology does not play any part in the funerary texts of New Kingdom royal tombs. The cultural milieu in which their decoration was designed seems, therefore, different from that reflected in BD chapters i 62 and I66. Although none of these considerations can be considered final proof against an early Ramesside date for BD chapter i 66, proponents of this interpretation would need to come up with positive evidence to support their claim.

After the tomb robberies of the late New Kingdom, high Theban officials including the clergy of the temple of Amun in Karnak were involved in the inspection of the tombs, and the priests later also reburied the kings. In year 6 of Herihor, Ramses II was reburied, perhaps in his own tomb (KV 7) (reburial phase A). Less than two decades later, in year I 5 of the 'king' and high priest of Amun Pinodjem I, he was reburied in the tomb of Seti I, together with that latter king as well as Ramses I (reburial phase B). We have presented evidence that on one of these occasions (or possibly a later, undocumented one), some of this king's old funerary equipment was adapted, while he apparently also received newly produced goods, including shabtis. It is entirely possible that the addition of BD chapter i 66 part I also goes back to this stage (or a later Twenty-First Dynasty episode about which we have no information). The fact that BD chapter I 66 part I continually refers to the dead king as $h m=k$, 'your Majesty', may have been a display of piety on the part of those responsible for the reburial, and one wonders if Herihor (A) or Pinodjem I (B), by carrying out the reburial in this fashion, wished to underscore the legitimacy of their own position, which involved the half-hearted assumption of a royal style besides their priestly titles. While this clearly belongs to the realm of speculation, it would fit the cultural context well. 
After reburial phase B, Ramses II rested undisturbed in his father's tomb for some time. Meanwhile, the Amun priests started a programme of reburying early New Kingdom kings and other royals in the tomb of queen Ahmose Nefertari (TT 320). At some point, Amenhotep I was also moved from his tomb to 'the $k 3 . y$ of Inhapy', which can now be identified as $\mathrm{KV}$ 39. In this period, our evidence only concerns the reburial of kings.

However, during the reign of Siamun, the already existing royal cachette in the tomb of Ahmose Nefertari was converted into a family tomb for the Amun clergy, which included the already present royal burials. In Siamun's year 5, the lady Nesikhons was buried in the tomb, in year ıo, her husband, the high priest Pinodjem II joined her. They were later joined by numerous other members of the priestly family.

The conversion of TT 320 into a family tomb did not imply an end to the reburial of New Kingdom royals. Three days before Pinodjem's burial, Ramses I, Ramses II, and Seti I joined Amenhotep I in 'the k3.y of Inhapy' (reburial phase C). When Pinodjem was buried three days later, they were moved again, this time to the tomb of Amenhotep I (reburial phase D). It is obvious that the simultaneous burial of Pinodjem in the tomb of Ahmose Nefertari and the reburial of these three great kings in Amenhotep's tomb was meant as a dramatic enactment establishing a direct connection between New Kingdom royalty and the Amun priesthood, set within the context of the cult of Ahmose Nefertari and Amenhotep I. The fact that the three Ramesside kings were, under Sheshonq I, again reburied (reburial phase E), being moved from the tomb of Amenhotep I to that of Ahmose Nefertari (TT 320) can easily be explained before the same background.

In burials datable to or just after the time of Pinodjem II, small papyri inscribed with BD chapter $\mathrm{I} 66$ suddenly turn up in great numbers. ${ }^{109}$ A possible explanation is that the text had only just become available, being discovered on the mummy of Ramses II in the preparation of reburial phase C. At this stage, the shabtis with which Herihor had perhaps supplied the mummy might also have been noticed. We suggest that the papyrus, after having been discovered, stirred great interest and was immediately widely adopted in burials of the Amun priesthood. However, what they received in their tombs was not a copy of the royal text (comprising only what we have called part I). Part II was added, and only this part concerned the dead priests. ${ }^{\text {Io }}$ It includes the shabti passage, perhaps inspired by the find context. ${ }^{\text {II }}$

Pinodjem II's burial, orchestrated with the simultaneous reburial of the early Ramessides in the tomb of Amenhotep I, must have been well-prepared already during

\footnotetext{
109 Around the same time, another funerary text written in Late Egyptian appears in the tomb of Nesikhons, Pinodjem's wife; see n. 58 .

${ }_{110}$ In P. Berlin $303 \mathrm{I}$ the reference to $h m=k$ was at one place supplemented with the name of the deceased, suggesting identity. In most sources, however, the name of the deceased and the designation $h m=k$ are kept strictly

There is another aspect to the shabti passage that has not hitherto been discussed in this context. Our interpretation of the facts entails that part II was added around the time of the death of Pinodjem II. In the same period, the Rogers tablet and the McCullum tablet were written (see n. 92). These are oracular decrees in which Amun sanctions the effectivity of the shabtis, referring to the fact that they have been or, partly, will be duly paid for (B. Menu, 'Les ouchebtis de Neskhons, entre droit et croyances: Tenants et aboutissements d'un décret oraculaire', ENiM 4 [201 I], 39-49). The fact that the topic of due payment for shabtis is raised both here and in BD i 66 part II, texts that were closely contemporary, may suggest that both reflect more widespread religious
} apart. ideas. 
Pinodjem's pontificate. One can only speculate about what motivated the move, but it seems not too adventurous to guess that the reburial was presented as a pious deed, which also suggested a kind of continuity between the Ramessides and the Amun priesthood. It may at the same time have been hoped that this action might incite the dead kings to exert their positive influence in the netherworld to the benefit of Pinodjem and his family. This also suggests that reburial in royal cachettes was not simply a way to protect the royal mummies, as is often believed, but that it was a deeply theological act.

The composition of BD chapter I 66 is highly interesting. Part I was transmitted in its original form, guiding $h m=k$ (i.e. Ramses II) through a process in which he was in the netherworld identified with $M-m-r-m-k-h-b$, a form of Osiris, the judge of the netherworld. Each time the text was reproduced for a private individual, it was not, therefore, this person that directly took the benefit, but Ramses II's netherworldly existence was reinvigorated. As a result, he also became a person entitled to take legal decisions in the netherworld.

In part II, the dead clergymen and -women benefited indirectly from this, because it was $M-m-r-m-k-h-b /$ the king who took legal steps to ensure their well-being in the nether-world by providing them with 'a donation to exert $b 3 w$-power and $h t p$-peace like your majesty (...)' and also to force their shabtis to work for them. After all, the text explains, their owner had duly paid for them, and the king was therefore expected to confirm them in their legal right over their work force.

The text ends with a statement to the effect that $h m=k$ (i.e. Ramses II) should work in this fashion every time the deceased recited this text. The arrangement was to mutual benefit: it ensured that the dead priest would eternally recite a text leading to the king's netherworldly existence, and in recompense, the king would support them.

The evidence we have presented can be read at two levels. The burial of Pinodjem II can be regarded as a large-scale display of piety to the great kings of the past. Although we have no texts explaining what Pinodjem expected from this exactly, it is psychologically likely that he regarded his acts towards these pharaohs as an incentive to receive a similarly beneficial treatment from them in return. At a much less grand scale, all other priests buried with a copy of BD chapter i 66 did something similar: they also ensured the eternal well-being of the king, and asked him for his assistance in return.

One can look at these texts (as we have done so far) from the perspective of the deceased. In death, the dead papyrus owners reciting the text act to the benefit of Ramses II, who will reward them for their piety. However, it is inherently unlikely that these texts were just attached to the mummies without further ado. One passage in part I in fact concerns a ritual act: the application of the name $M-m-r-m-k-h-b$ to the mummy of $h m=k$. This implies that, before the text started functioning of its own accord in the tomb, a human agent was involved in getting it working, perhaps by reciting it. If our interpretation is correct, the person responsible for this might well have been Pinodjem I (or an official acting for him). ${ }^{112}$ We would like to end on a tentative note. If we suppose

\footnotetext{
II2 Until now, we reckoned with the alternative possibility that Herihor might have been responsible for the application of the papyrus during reburial phase A. Having come to the end of our analysis, it has, however, become likely that the papyrus was discovered during reburial phase C. Since the mummy was apparently rewrapped in connection with reburial phase B, a papyrus applied under Herihor during phase A would probably
} 
that Pinodjem I was effectively reciting the text, and inscribing Ramses' mummy with the name $M-m-r-m-k-h-b$, the earthly ritual in fact follows a pattern resembling that of the acts of the dead king in the netherworld for Osiris/M-m-r-m-k-h-b. It is not easy to understand all the underlying ideas that may have been of influence. But we see before our eyes the high priest Pinodjem I, who has also taken on a royal rank. In the uncertain years of his tenure, we see him piously reburying Ramses II, and supplying him with a text in which he respectfully addresses him as $h m=k$. By bringing Ramses II back to life in this fashion, he in fact plays the role of the king's successor. This may have been seen as a powerful act to bolster his poorly founded legitimacy as a king. Later, in the second half of the Twenty-First Dynasty, (dead) Amun priests followed in his footsteps, in the netherworld reciting the text, and in return likewise expecting benefits from Ramses II.

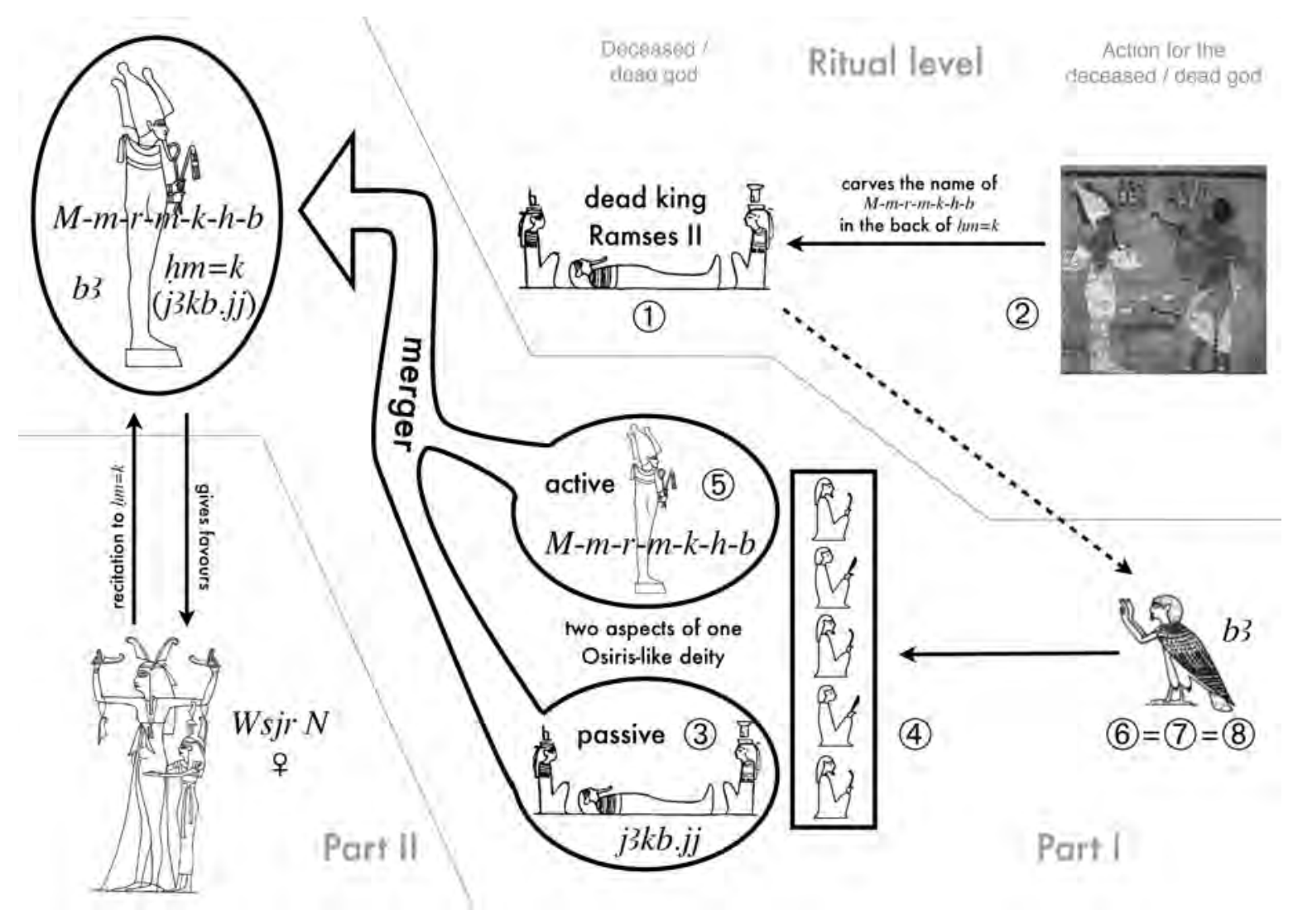

FIG. I. Schematic rendering of the interactive patterns in Book of the Dead Supplementary Chapter 166. (Drawing by Martin Pehal.)

have been removed before or during phase B, and unless it was reattached to the mummy it could not have been found in phase C. Although certainty on this point cannot be expected, we will assume in what follows that Pinodjem I applied the original version with part I. 